\title{
Entrepreneurship Theory and Practice
}

\section{A System Justification Theory of Entrepreneurial Attitudinal Change During a Crisis}

\begin{tabular}{|c|c|}
\hline Journal: & Entrepreneurship Theory and Practice \\
\hline Manuscript ID & ETP-2020-06-PP-0004.R5 \\
\hline Manuscript type: & Paper submission to a special issue \\
\hline Keywords: & $\begin{array}{l}\text { crisis, foreign entrepreneurs, system justification theory, liability of } \\
\text { foreignness, Middle East }\end{array}$ \\
\hline Abstract: & $\begin{array}{l}\text { Entrepreneurship resilience during a crisis is an important research area. } \\
\text { However, prior research has not examined cognitive antecedents of } \\
\text { entrepreneurial resilience. Using the } 2014 \text { oil price crisis in the Middle } \\
\text { East as a natural experiment, we draw on system justification theory to } \\
\text { understand why and how entrepreneurs differ in the extent of their } \\
\text { attitudinal changes toward corruption. We find foreign entrepreneurs } \\
\text { substantially increased their willingness to engage in corruption whereas } \\
\text { local entrepreneurs did not. Among foreign entrepreneurs, corruption } \\
\text { willingness increases more among those from countries where corruption } \\
\text { is not the norm, than those from more corrupt home countries. }\end{array}$ \\
\hline
\end{tabular}




\section{A System Justification Theory of Entrepreneurial Attitudinal Change Toward Corruption During a Crisis}

\section{Introduction}

A crisis is an unexpected, rare, but high-impact event that threatens economies, businesses, and entrepreneurs in powerful ways (Pearson \& Clair, 1998). Since crises can have significant implications for entrepreneurship, some entrepreneurship studies examine crises in the context of entrepreneurial activity and success (Davidsson \& Gordon, 2016; Doern, 2016; Doern, Williams, \& Vorley, 2019; Shepherd \& Williams, 2018). A particular interesting issue is how entrepreneurs demonstrate their resilience in the face of crises. Entrepreneurship scholars have examined responses such as adaptation and disengagement (Davidsson \& Gordon, 2016), self-efficacy (Bullough, Renko, \& Myatt, 2014), resources (De Carolis et al., 2007), social capital (Salvato, et al., 2020), and persistence (Chirico, Gomez-Mejia, Hellerstedt, Withers, \& Nordqvist, 2019). Since cognition is a central driver of entrepreneurship (Mitchell, Busenitz, Lant, McDougall, Morse, \& Smith, 2002), cognitive factors should also play an important role for entrepreneurs during a crisis. Entrepreneurship scholars have suggested us to focus on how entrepreneurs cognitively react because cognitive adaptation or change often precedes entrepreneurial judgment and actions (Haynie, Shepherd, \& Patzelt, 2012; Chadwick \& Raver, 2020).

However, prior research on entrepreneurial resilience has not examined how and why entrepreneurs may differ in the level of their cognitive adaptation during a crisis. This is an important gap in the crisis - entrepreneurship literature for a few reasons. First, our understanding of entrepreneurial resilience would be incomplete without understanding how and why different entrepreneurs would cognitively react during a crisis. Because entrepreneurial cognition is about how entrepreneurs use simplifying mental models to process information (Mitchell, et al., 2002), this cognitive process is particularly important for understanding their adaptation during a crisis, or how they can "grow from adversity" (Bullough, et al., 2013). This cognitive emphasis would complement prior research on crisis and entrepreneurship that has examined resources (De Carolis et al., 2007) and social capital (Salvato, et al., 2020), since most entrepreneurs often lack financial and social resources 
at their disposal during a crisis. Second, because a crisis is often compounded with institutional complexities, a study that examines the interplay of a crisis, cognition, and institutional factors would extend this cognition - crisis perspective in new ways. Institutional contexts can shape the directions of cognitive adaptation, adding novel insights to the growing literature of entrepreneurial resilience.

In this study, we focus on one cognitive aspect—attitudes among entrepreneurs toward local institutional norms such as corruption because attitudes and the transformation of attitudes often affect judgment and behavior (Gregoire, Corbett \& McMullen, 2011). By drawing on system justification theory (SJT) (Jost et al., 2004; Jost, 2019), we examine how and why some foreign entrepreneurs adjust their attitudes toward corruption during a crisis more than local entrepreneurs. We use a unique dataset of entrepreneurs from seven oil-producing Middle Eastern countries where corruption is a pervasive local social norm (Hafez, 2009). Using the oil crisis of 2014 as a natural experiment, we conduct a difference-in-difference analysis to investigate how this crisis affects foreign entrepreneurs' attitudes toward corruption, compared with local entrepreneurs. We extend SJT and suggest that the crisis triggers significant attitudinal changes among disadvantaged entrepreneurs such as foreign entrepreneurs, but not among advantaged entrepreneurs such as local entrepreneurs. We further suggest that the extent of attitudinal change for foreign entrepreneurs depends on the level of corruption in their home country. Foreign entrepreneurs from a home country where corruption is not the norm would have greater attitudinal changes than those foreign entrepreneurs from a corrupt home country.

This study makes several contributions to the entrepreneurship literature. On the theoretical front, our study extends SJT by identifying crises as potentially important triggers of attitudinal change and by integrating the liability of foreignness (LOF) into SJT. First, SJT is ambivalent about the conditions under which a disadvantaged group may change their attitudes, and our study highlights how a crisis can trigger such attitudinal change. As a crisis represents a situation of acute stress and uncertainty, a disadvantaged group may be more likely to adopt prevailing values and attitudes held by the advantaged group. Second, SJT is mainly concerned with dynamics caused by social justice (Jost et al., 2004), however, our study identifies a novel distinction in relation to the advantaged versus disadvantaged groups by integrating the LOF. We extend the scope of interests to a 
new social category as defined by foreignness. The effects of LOF can be multidimensional (Zaheer, 1995; Eden \& Miller, 2004). Foreign entrepreneurs' attitudes toward the local prevailing norms such as corruption become a novel and relevant subject that prior literature of SJT has not considered.

Furthermore, our study contributes to the crisis-entrepreneurship literature by focusing on how and why different entrepreneurs exhibit different levels of cognitive adaptability. A crisis can be a powerful catalyst that disrupts pre-existing cognitive structures before the entrepreneur is able to reconsider and realign her relationship with the external environment. In our study we analyze the variance of attitudinal change, an outcome previously not examined but important for driving entrepreneurial resilience during the crisis.

\section{Crises and Entrepreneurship}

Pearson and Clair (1998, p. 66) define a crisis as "a low-probability, high-impact situation that is perceived by critical stakeholders to threaten the viability of the organization.” A crisis, although rare, often reshapes the environment in extraordinary ways that were otherwise not possible. For example, recent crisis events have shaped our society in general and entrepreneurship in particular, including the 9/11 terrorist attacks (2001), the global financial crisis (2007-2008), Hurricanes Katrina (2005), Harvey (2017) and Irma (2017), and the recent COVID-19 crisis (2020). The manner in which an entrepreneur deals with these high-impact, low-probability situations can determine whether the entrepreneur survives these events.

Within the field of entrepreneurship, there has been a recent increase in the number of studies about crises (Davidsson \& Gordon 2015; Doern 2016; Doern et al., 2019; McMullen \& Kier, 2016; Williams \& Shepherd 2016; Williams \& Vorley 2015). One important issue revolves around how entrepreneurs can mitigate the negative effects of a crisis. De Carolis et al. (2009) show that firmspecific resources are key to flexibility and competitive advantage in the face of adverse events. Smallbone et al. (2012) find that small businesses in the UK and New Zealand were able to show resilience with a high level of adaptability and flexibility during the global financial crisis. Grube and Storr (2018) find that embedded entrepreneurs are able to facilitate community recovery in postdisaster contexts by supplying needed resources to victims and leveraging their social capital. 
Sometimes entrepreneurs may not take any action specifically but carry on in a 'business as usual' fashion (Davidsson \& Gordon, 2016). Salvato et al. (2020) find that family social capital is critical to the survival of family firms after a natural disaster. Some entrepreneurs are resilient, adjusting and maintaining the functioning of their ventures prior to, during, and following adversity (Williams, Gruber, Sutcliffe, Shepherd, \& Zhao, 2017). By contrast, McMullen and Kier (2016) show that escalation of commitment can blind entrepreneurs from detecting the emergence of a crisis and forming effective exit strategies in the events of the 1996 Mount Everest disaster.

While these prior studies lay solid foundations for future research, an important factor linking a crisis and entrepreneurial resilience — entrepreneurs' cognitive adaptation—is absent from prior research. The cognitive characteristics of entrepreneurial decision making have been a central theme in entrepreneurship research (Baron, 1998; Mitchell, et al., 2002; Baron \& Ward, 2004; Gregoire, et al., 2011). The psychological make-up or mental models constitute an important foundation of entrepreneurial resilience and survival during a crisis (Haynie, et al., 2012; Chadwick \& Raver, 2020). Cognitive adaptation can be particularly important when entrepreneurs are hit by a crisis because they often lack financial and social resources particularly during a crisis, and their cognitive adaptation including attitudinal change often precedes their decision-making and other adaptive moves to survive the crisis (Chadwick \& Raver, 2020).

We focus on attitudes because attitudes are learned predispositions to objects and are liable to change as circumstances change (Bohner \& Dickel, 2011; Albarracin \& Shavitt, 2018). Attitudes and attitude changes can influence an individual entrepreneur's judgment and behavior as surrounding dynamics change (Gregoire, et al., 2011), such as in a crisis situation. In various institutional contexts, entrepreneurs develop their attitudes toward some prevailing norms in specific, daily interactions with the institutional environment. Institutional specificity, therefore, would guide and shape the process of cognitive adaptation by influencing what specific attitudes of entrepreneurs need to be adapted. In this study, we examine how attitudes toward a specific norm such as corruption, which is particularly important in some institutional environments, may or may not change during a crisis, depending on different categories of entrepreneurs. 


\section{The 2014 Oil Price Shock}

The Middle East produces about one third of the world's oil, and while it has become affluent based on its abundant resources, the oil market fluctuates, sometimes violently. Oil prices slumped from a peak of $\$ 115$ per barrel in June 2014 to a low of $\$ 35$ in Feb 2015 (Kilian, 2015). This precipitous drop in oil prices is attributed to several factors working simultaneously, including a slowing worldwide demand, more competition from fracking extraction in the US and Canada, and countries like Saudi Arabia strategically lowering prices to grab market share. The price slump reduced oil export revenues, inward investment in oil sectors, and government revenues, making international loans more difficult to obtain and slowing economic growths in oil producing countries (Hou, Keane, Kenan, \& Velde, 2015). For example, Saudi Arabia, the largest and strongest economy in this region, saw its income from oil fall by $23 \%$, and was hit by a budget deficit of over $\$ 100$ billion in 2015 (BBC, 2016). Figure 1 shows historical oil prices between 2010 and 2018. -----------Insert Figure 1 about here-

The oil price shock significantly changed the resource environment of the Middle East. Most oil exporting countries in the region introduced a sales tax for the first time to help alleviate fiscal problems. The UAE removed long-standing fuel subsidies (Ellyatt, 2016). As the cash flows within local economies dwindled, their private sectors were also affected. Entrepreneurs found themselves dealing with an environment in which resources were depleted.

\section{System Justification and Entrepreneurs' Attitudinal Change Toward Corruption}

Individual entrepreneurs may react to a crisis in different ways, depending on their specific identities. Entrepreneurs in the Middle East may be local or foreign. Local entrepreneurs are those born and raised in the country in which they are now operating, whereas foreign entrepreneurs have travelled from their home countries to reside and seek entrepreneurial opportunities in the host country (Kulchina, 2016, 2017; Liu et al., 2020). These two groups of entrepreneurs differ in several respects. First, local entrepreneurs are often more embedded in local communities and can leverage their social connections better than foreign entrepreneurs. Second, local entrepreneurs are more aligned with local cultures and norms because their education and social experiences have been 
framed by those norms (Spicer et al., 2006). Third, foreign entrepreneurs suffer from the liability of foreignness (LOF), that is, the additional costs and difficulties associated with the lack of experiences in the local environment (Zaheer, 1995).

The disadvantages for foreign entrepreneurs are multidimensional, including economic, social and sometimes social psychological disadvantages. Eden and Miller (2004) categorize LOF into three dimensions: 1) unfamiliarity hazards; 2) relational hazards; and 3) discrimination hazards. For example, Middle Eastern countries have implemented foreign ownership laws that stipulate specific ownership restrictions for foreign owners, even though several countries such as the UAE and Saudi Arabia have sought to lift these restrictions recently (Mohammadian-Molina, 2020). Foreign entrepreneurs often take longer to obtain a business license and, in setting up their ventures in the Middle East, they are required to have a local sponsor (Odeh \& Sahlawi, 2020). Therefore, the distinction between local versus foreign entrepreneurs means a difference in statuses and identities: local entrepreneurs are more advantaged than foreign entrepreneurs, which determines different reactions by these two groups to the prevailing norms and systems.

This social identity difference between local and foreign entrepreneurs would determine their different levels of attitudinal changes during the crisis of 2014, according to system justification theory. System justification theory (SJT) is a social psychology theory that focuses on stereotyping and intergroup relations (Jost \& Banaji, 1994). The central thesis of SJT proposes that people actively defend and bolster existing social arrangements or "systems," often by denying or rationalizing injustices and other social problems, even when doing so can jeopardize their personal and group interests (Jost, Banaji, Nosek, 2004). The term "system" here refers to any social, economic, or political arrangements in which individuals are embedded, ranging from small scale systems such as the nuclear family to large-scale systems such as the government or the capitalist economy (Wakslak, Jost, \& Bauer, 2011). In other words, "system" may not treat everyone equally, and may treat the disadvantaged group particularly unfairly. However, the distinctive prediction from SJT is that those individuals in disadvantaged groups sometimes participate in justifying the status quo, or the system, an issue called outgroup favoritism (van der Toorn \& Jost, 2014). In the Middle East, corruption 
stands out as an important and relevant component of the local social system (Hafez, 2009; Tomass, 2012; Touati, 2014). For example, an Ernst \& Young (2014, p. 5) survey of multinational corporations operating in the Middle East found, "[Corruption] is a common issue but a traditional business way in the past ... you just can't do a thing, or think you can't, without paying. Sometimes this is regarded as a legitimate expense."

System justification is conceptualized as a motivational process that varies in strength based on both internal and external factors (Jost et al., 2010). SJT research has identified several antecedents such as uncertainty avoidance, intolerance of ambiguity, needs for order and structure, perception of a dangerous world, and fear of death as positively associated with system justification; cognitive complexity and openness to experience are negatively associated with system justification. Particularly fitting to our context of a major economic crisis, the crisis situation would heighten the need for uncertainty avoidance, the need for order and structure, and the perception of a dangerous world that can trigger the system justification motivations (van der Toorn \& Jost, 2014). In terms of consequences of system justification, the most notable effect of system justification is the palliative function or decreasing negative affect and increasing positive affect and satisfaction with one's situation (Jost, et al., 2003).

The advantaged group differs from the disadvantaged group during the system justification process in several respects. First, these two groups differ in their social identities, which in turn position them differently within the system. The advantaged group is more integrated with the system and benefits from the status quo, whereas the disadvantaged group does not. Second, and more importantly for our study, members of the disadvantaged group are faced with a potential conflict between system justification and the competing motive to enhance their own self-esteem and group status, whereas this conflict is not present for members of the advantaged group (van der Toorn \& Jost, 2014). The disadvantaged group often struggles between these two opposing demands, one submitting to and justifying the "fairness" of the system and the other maintaining self-esteem and elevating their in-group status. For the disadvantaged group, maintaining self-esteem is at odds against justifying the system as fair and appropriate. By contrast, for the advantaged group, system justification is consistent with maintaining their self-esteem and group status. In other words, this 
internal motivational conflict makes it difficult for the disadvantaged group to justify the system, but not so for the advantaged group, under normal circumstances. SJT is ambivalent about what conditions would prompt the disadvantaged group to overcome such motivational conflict. In this study, we suggest that, in the time of a crisis, the increased demand for uncertainty avoidance, order and structure, and stress would trigger the demand to switch and justify the "fairness" of the system for the disadvantaged group. The crisis constitutes an exogenous push for the disadvantaged group to overcome the hurdle of motivational conflict associated with system justification.

An external crisis disrupts a firm's operating environment and, if mismanaged, has the potential to devastate it and exhaust its resources (James, Wooten, \& Dushek, 2011). At the individual level, a crisis creates emotional distress that challenges the validity and effectiveness of an individual's value systems (James et al., 2011). It may cause an individual to deviate from her normal approach to sense-making (Weick, 1993; 1996). Whereas the disadvantaged, foreign entrepreneurs may not justify the prevailing system or corruption as being fair or acceptable under normal circumstances, a major crisis may change their sense-making, attitudes, and other psychological make-up. A situation like the 2014 oil price crisis creates chaos, depletes resources, and pressures foreign entrepreneurs to reconstruct their value systems in order to adapt to a radically different environment. Like the firefighters at Mann Gulch (Weick, 1993; 1996), foreign entrepreneurs need to drop their tools, overcome their motivational conflict when considering norms such as corruption, and readjust their attitudes toward corruption to be more aligned with the environment impacted by the crisis. They must unlearn old attitudes and adopt prevailing, local ones.

By changing their attitudes, foreign entrepreneurs are able to achieve several effects. First, at the individual level, system justification increases satisfaction with the status quo, a palliative effect that enhances individual well-being, reduces uncertainty, and relieves foreign entrepreneurs from the tension between old attitudes, either anti-corruption or neutral, and the local prevailing pro-corruption norms (Jost, 2019). Second, changing attitudes serves the relational needs of foreign entrepreneurs because doing so makes it easier for them to navigate social relationships with local entrepreneurs and achieve a sense of shared reality (Jost \& Hunyady, 2005). Such social accord is particularly relevant in the post-crisis society where a sense of community and citizenship is emphasized (Meyer et al., 
2020). In other words, the crisis triggers foreign entrepreneurs to overcome the motivational conflict and switch to justify the system by changing their attitudes toward corruption, but such motivational conflicts are absent among local entrepreneurs, and hence, no such attitudinal change develops for local entrepreneurs during the crisis. Therefore, we hypothesize the following:

Hypothesis 1: The crisis leads to a greater increase in the level of corruption willingness among foreign entrepreneurs than among local entrepreneurs.

While SJT primarily focuses on the categorical difference between the advantaged group (local entrepreneurs) and the disadvantaged group (foreign entrepreneurs), there is a within-group variance among foreign entrepreneurs. SJT is concerned with social justice where the categorical distinction is generally clear-cut, such as gender, race, or political ideologies (Jost, 2019). The LOF, by contrast, is a relative concept (Zaheer, 1995). In our context, this relative difference depends on differences between their home countries and host countries in terms of corruption. Home countries imprint foreign entrepreneurs with initial values, beliefs, attitudes, and experiences (Godinez \& Liu, 2015). Fisman and Miguel (2007), for example, showed that diplomats from different countries react differently to a change of law in relation to traffic fines in New York because home country norms can have a persistent impact on corruption even in a new host country. In that seminal study (Fisman \& Miguel, 2007), those diplomats from low-corruption countries such as Norway received much fewer parking tickets compared with other diplomats from high-corruption countries such as Nigeria, when they had diplomatic immunity from ticket fines during their work at the United Nations Headquarters in New York. In 2002, the New York city administration implemented a stringent legal enforcement change: those diplomats could lose their diplomatic license plates if they accumulated more than three parking violations, which caused a massive decline of 98 percent in parking violations among diplomats (Fisman \& Miguel, 2007). Norm imprints from home countries could precondition these entrepreneurs differently in their adaptation to local norms.

Some foreign entrepreneurs come to the Middle Eastern countries cognitively more prepared for corruption than others. These foreign entrepreneurs are typically from India, China, Somalia, Libya, or Sudan, which have low scores on Transparency International's Corruption Perceptions Index (CPI), an international watchdog for corruption issues. They often have prior exposure to 
corruption or believe that corruption is a normal part of business practices. For example, Budak and Rajh (2014) find that entrepreneurs from Bulgaria have knowledge of corruption tactics and tend to justify corruption as a legitimate way to "grease the wheels." Foreign entrepreneurs from more corrupt home countries suffer less from cognitive dissonance regarding corruption (Godinez \& Liu, 2015). When there is a crisis in the host countries, these foreign entrepreneurs' familiarity with corruption means they are less stressed, show less outgroup favoritism, and are not expected to change their attitudes to corruption because they, although foreign, already hold similar attitudes as local entrepreneurs. They are more receptive to the prevailing values and norms and less likely to make post-crisis attitudinal changes regarding corruption when a crisis occurs.

By contrast, foreign entrepreneurs from less corrupt countries are not as cognitively prepared for corruption and suffer cognitive dissonance to a greater extent when they operate in host countries that are more corrupt than their home countries. Due to the persistent influence of home country norms on corruption, these foreign entrepreneurs continue to deal with external stakeholders using their prior attitudes and beliefs. Under normal conditions, home country imprints have constrained their adaptation to local norms, like those diplomats in Fisman and Miguel (2007). However, the economic crisis in the Middle East acts as an acute external stimulus that prompt significant changes among these foreign entrepreneurs by counteracting the cognitive constraints of home country imprints. The major economic crisis has presented an existential threat to foreign entrepreneurs in the sense that if they were not able to adapt, their survival would be at stake. The external event requires entrepreneurs to realign their attitudes with a new set of environmental conditions, which in the case of a major economic event in our study increased both uncertainty of the environment and the survival benefits of corruption in the Middle East. While foreign entrepreneurs who are used to corruption norms do not need to change attitudes, significant changes are needed for those foreign entrepreneurs from low-corruption home countries who used not to conform to corruption norms. These foreign entrepreneurs from "clean" home countries need to go through a cognitive process of unlearning, and then learning to adapt to the stressful and more difficult post-crisis environment, exhibiting a greater extent of attitudinal changes. Home country imprints interact with the effect of the economic crisis in 
co-determining different extents of attitudinal changes among foreign entrepreneurs. Therefore, we propose:

Hypothesis 2: The crisis leads to a greater increase in the level of corruption willingness among foreign entrepreneurs from less corrupt home countries than those from more corrupt home countries.

\section{Methods}

\section{Data and Sample}

We use the oil price crisis of 2014 as a natural experiment to examine how attitudes toward corruption may drastically change in a short period of time. The study focuses on entrepreneurs operating in seven oil-producing Arab League member countries-Bahrain, Egypt, Kuwait, the Kingdom of Saudi Arabia (KSA), Oman, Qatar, and the United Arab Emirates (UAE). The economies of these countries all depend on oil exports. Data from the World Bank suggest that in 2013, Kuwait was most reliant on oil exports with 57.4\% GDP while Egypt is least dependent with 7.8\% GDP in oil industries.

We collected data from several sources. The primary data source is a survey administered to small business owners by the Economic and Social Council of the Arab League Countries, which is a joint institution coordinating economic integration among Arab speaking countries. To facilitate anticorruption campaigns within these Arab countries, the survey is administered annually. The structure of the survey is similar to the data on corruption collected by the World Bank and prior studies (Cull \& Xu, 2005; Iriyama, Kishore \& Talukdar, 2016).

An electronic survey was conducted in either English or Arabic during annual business license renewal. The administrators of the survey took several steps to enhance the integrity of the data. First, the survey was administered anonymously, and the system did not collect primary personal information such as names and addresses. Second, survey respondents were guaranteed that the answers on the survey would not be used against them in the court of law or to activate criminal investigations against them. Third, the questions were randomly assigned to individual respondents. For example, respondent 1 may see Q1, Q2, Q3 and then see Q9, Q6, Q4, and so on. However, another respondent would see these questions in a different random order, which minimized issues such as bias. Fourth, to check for any irregularities in the survey answers, the administration system 
recorded the time each respondent took to fill out the survey. The administrators then inspected each survey answer carefully and examined the response time to decide whether the answers were indeed genuine or not. Generally, respondents spent 14 minutes on average to answer all survey questions. If a person completed the survey in fewer than 14 minutes, administrators checked for problems and if they found any, they eliminated the response from the database.

The council took several steps in the sampling process to arrive at the current sample size. First, the survey was attached to all new business license applications in the host countries. The council limited the survey's scope to firms that were newly established in 2013 , with 55,876 surveys administered. Second, the council targeted sole proprietors, reducing the sample to 22,933 newly established firms with sole proprietors. Third, the survey had a "no response option" next to each survey question, which allowed respondents to take the survey voluntarily, reducing the sample to 10,756 surveys (19\% response rate). After removing surveys with irregularities, the sample size was 1,728 individuals with 8,587 surveys. The survey provided repeated measures from 2013 to 2018 as the same entrepreneurs responded annually at business license renewal, with each respondent assigned a unique ID in the database. We compared respondents with non-respondents to examine whether they were statistically different. Because our sample uses panel data, where respondents repeatedly entered the sample, violating the independence assumption of the $t$-test (Pandis, 2016), we conducted $F$-tests with observations clustered around host countries. The $F$-test based on venture size had an $F$ value of 0.45 , with a probability value of 0.52 , showing no statistically significant difference between the respondent sample and non-respondents.

In terms of the distribution between locals and foreigners in our sample (1,595 individual entrepreneurs), $51 \%$ were local entrepreneurs ( 818 individual entrepreneurs) who resided in the seven host countries, and foreign entrepreneurs (777 individual entrepreneurs) accounted for $49 \%$. Figure 2 maps the locations of entrepreneurs, both local and foreign, in the seven countries of our sample, based on the 2013 records. In 2013, Egypt had the largest group of entrepreneurs with 359: 142 foreigners and 217 locals. Kuwait had the smallest group of 155 entrepreneurs: 32 foreigners and 123 locals. 
We also analyzed the distribution of foreign entrepreneurs in the sample based on their home country information. As shown in Table 1, the sample is quite diverse in terms of home countries as these entrepreneurs came from 60 countries. India has the largest number of entrepreneurs, with 134 entrepreneurs, or $18.1 \%$ of the foreign entrepreneur sample, followed by the UK with 86 entrepreneurs or $11.7 \%$. In other words, most foreign entrepreneurs in our sample came from outside the region.

\section{---------Insert Table 1 about here--------}

Additional data were collected from multiple sources such as the World Bank, Transparency International, World Economic Forum, and the Lauder Institute to construct control variables in the analyses.

\section{Variables and Measures}

\section{Dependent Variables}

Corruption willingness, defined as the individual's willingness to engage in corruption (Agbo \& Iwundu, 2016; Dickel \& Graeff, 2018), captures individual attitudes regarding how acceptable, appropriate, and effective the individual considers corruption (Dickel \& Graeff, 2018). We used 11 survey items measuring entrepreneurs' perception of corruption, its effect on their ventures, and their willingness to utilize corrupt opportunities to further their ventures (see Appendix 1 for details). We conducted a multilevel exploratory factor analysis to account for the repeated measures and the longitudinal nature of the survey items (Reise, Ventura, Nuechterlein \& Kim, 2005). The analyses showed a Cronbach $\alpha$ of 0.97 , suggesting a high level of reliability. We used this principal component factor analysis to construct our measure of corruption willingness, with the analysis loaded on one factor with an Eigenvalue over 1 to indicate corruption willingness. A higher score indicates a higher level of corruption willingness, and a lower score a lower level of corruption willingness.

\section{Explanatory Variable}

Oil price shock is a dummy variable with a value of 0 indicating the period from 2013 to 2015 before the shock hit the Middle East in 2015, while a value of 1 indicates the post-shock period from 2016 to 2018. Foreign entrepreneur is a dummy variable taking the value 0 when an entrepreneur is 
local, meaning that the individual is a local resident from one of the seven host countries, and 1 when an entrepreneur is from countries other than the Middle Eastern countries.

CPI difference is captured by a dummy variable. The CPI is annually published by Transparency International (Godinez \& Liu, 2015). A high index score indicates a relatively low level of corruption in a country, whereas a more corrupt country has a low index score. The variable takes the value 1 if the CPI score of an entrepreneur's home country is higher than that of their host country, meaning the entrepreneur is from a less corrupt home country compared with the host country in which the entrepreneur resides. Otherwise, the variable takes the value 0 .

\section{Control Variables}

We controlled for several individual-, firm-, industry-, and country-level factors in the analyses. The individual level control variables include age, gender, experiences, and contacts. Age group of an entrepreneur is a categorial variable for how old the entrepreneur is, ranging from 1 to 5 to indicate $18-27,28-37,38-47,48-57$, and 58-67 respectively. Gender of an entrepreneur takes a value of 1 if the entrepreneur is a male, or a value of 0 for females. We also controlled for prior entrepreneurial experience, measured as the number of prior ventures an entrepreneur has undertaken before (Toft-Kehler, Wennberg \& Kim, 2014) and the number of contacts an entrepreneur has dealt with in the host country such as officials or middlemen (Miller, Steier \& Breton-Miller, 2016). The firm-level controls include venture size, measured by the number of employees in the firm, and the sector in which an entrepreneurial venture was primarily involved. We measured the sector using a categorial variable indicating seven industry sectors. The variable ranges from 1 to 7 to indicate the Construction, Consulting, General Trade, IT, Import/Export, Real Estate, and Tourism industries, respectively. We controlled for industry share as the percentage of host country GDP to account for the importance of the industry in the host country. We also controlled for host country GDP growth to factor in the influences of economic growth of the host country. All models included the country fixed effects of the seven host Arabic countries.

\section{Empirical Analyses}


The natural experiment design revolving around the 2014 oil price shock allows us to better understand the underlying causality (Siewke \& Santoni, 2020). In our design, local entrepreneurs are the control group whereas foreign entrepreneurs are the treatment group. The 2014 oil price shock allows us to focus on the effects of identity difference between foreign and local entrepreneurs on attitudinal changes. Our study focuses only on the attitudinal changes triggered by the 2014 oil price shock, and thus provides a valid test of causality of our hypothesized relationships. For instance, Beaman et al. (2012) used a natural experiment of having female leaders in randomly selected village councils according to a 1993 law to show that parental aspirations for boys are unchanged after the passing of this law while parent's aspirations for girls significantly increased. Similarly, our design aims to show that foreigners are more receptive to corruption after the crisis, while local entrepreneurs do not experience similar attitudinal changes.

To fully exploit the natural experiment opportunity presented by the 2014 oil shock, we used a difference-in-difference approach to test H1. The distinction of foreign versus local entrepreneurs represents our treatment, whereas the post-shock period would fit into the time specification of the difference-in-difference approach in testing H1. One critical assumption for applying the differencein-difference analysis it to ensure the treatment and control groups have parallel trends in outcome, meaning that in the absence of the treatment, the difference between the treatment units and control units in the outcome remain constant over time. To alleviate concerns over whether foreign entrepreneurs are comparable with local entrepreneurs, we employed the matched difference-indifference approach (Stuart et al., 2014). In the first step, we applied propensity score matching to match the foreign entrepreneurs to the local entrepreneurs based on the same observed characteristics (i.e., gender, age, prior entrepreneurial experience, number of contacts, venture size, and industry). This method ensures that the two groups, foreign and local, are comparable and the parallel trend assumption continues to hold (Stuart et al., 2014). In the second step, we conducted the difference-indifference analysis using the matched samples of entrepreneurs to estimate the differential impacts of oil shock on their corruption willingness, which removes the effects of time-invariant, unobserved, or confounding factors in the analysis. 
In terms of potential issues of sample selection bias in the analysis, our sample is an unbalanced panel data, meaning that some individuals dropped out of the sample at some point before 2018. Also, corruption may potentially increase the survival chances of ventures. Therefore, it is possible that entrepreneurial ventures that developed corruption tolerant attitudes survived longer and are overrepresented in the final sample. We first conducted a series of $t$-tests to analyze whether there is significant difference between the entrepreneurs remaining in the sample for the whole period of the study and those who dropped out before 2018. We then conducted Heckman two-stage analyses to account for the sample selection bias (Heckman, 1978, 1979). As a robustness test, we also employed panel regressions with the unbalanced dataset during the period of 2013 and 2018, which aims to test the interaction effect of oil shock and foreign identity on corruption willingness. The advantage of using panel regressions here is that we are able to test the main hypothesis (H1) by using the full sample, not just the matched sample of foreign and local entrepreneurs.

To test Hypothesis 2, we focused on the subsample of foreign entrepreneurs since the CPI difference is only relevant in that subsample. We then tested the moderating effect of the CPI difference on the relationship between oil shock and foreign entrepreneurs' corruption willingness. We conducted panel regressions with clustered robust standard errors to account for the correlation between observations associated with a same entrepreneur over time. Again, we factored in sample selection bias in the regression analyses.

\section{Results}

\section{Summary Statistics}

We presented the descriptive statistics and correlations of all the variables used in the analyses in Table $2 \mathrm{a}$ and $2 \mathrm{~b}$ for the full sample and Table $3 \mathrm{a}$ and $3 \mathrm{~b}$ for the foreign sample. In the full sample, $74 \%$ are male and $26 \%$ are female. The size of ventures ranges from 1 to 16 employees. On average, the sample entrepreneurs have established about two ventures prior to the current one and have nearly six local contacts. Entrepreneurs have a mean age of 36 . The correlations among all the explanatory variables are under 0.4 as shown in the correlation tables. Among all the foreign entrepreneurs in our subsample, $86 \%$ are male and $14 \%$ are female. The size of ventures ranges from 
four to 16 employees. The correlations between explanatory variables are all under 0.5 . VIFs values are mostly between 1 and 4, with the largest VIF (5.35) being the interaction term of oil shock and CPI difference, suggesting that multicollinearity was not serious in our analyses.

-------Insert Tables 2a, 2b, 3a, and 3b about here-------

The dependent variable of corruption willingness ranges from -2.8 as the lowest (least corrupt) to 2.02 as the highest (most corrupt). For the starting year of 2013, we analyzed the difference between local and foreign entrepreneurs. Local entrepreneurs have an average of -0.03 , while foreign entrepreneurs are averaged at -0.37 . The $t$-test shows a significant difference between these two groups at the 0.001 level with a $t$ value at 7.52 , suggesting that local entrepreneurs are more receptive to corruption than foreign entrepreneurs. For the final year of 2018, by contrast, corruption willingness among local entrepreneurs changed little with an average of -0.26 , whereas foreign entrepreneurs increased to an average of 0.65 . The $t$-test shows a $t$ value at -15.89 , but with foreign entrepreneurs showing a higher level of corruption willingness than local entrepreneurs.

This reversal is depicted in Figure 3, which plots the trendlines of corruption willingness of foreign and local entrepreneurs from 2013 to 2018. We aggregated all foreign entrepreneurs' corruption willingness to each year, starting from 2013 to 2018 . Then we plotted the trendlines for both foreign and local entrepreneurs respectively, for the periods 2013-2015 and 2016-2018. The dotted line indicates local entrepreneurs, and the solid one for foreign entrepreneurs. Figure 4 shows that the line indicating local entrepreneurs remains relatively flat and stable in the six-year time window, meaning that on average the shock of the oil price crisis did not significantly affect local entrepreneurs. By contrast, the solid line for foreign entrepreneurs shows a sharp rise in 2015 and the three remaining years thereafter, which coincides with the timing of the oil price crisis.

-------Insert Figure 3 about here-------

\section{The Effects of the Oil Price Crisis on Entrepreneurs' Corruption Willingness}

We analyzed the full sample to understand the potential impact of sample attrition and found that 366 of 1,595 (22.9\%) entrepreneurs exited earlier than 2018, the end of our sample. Among these 366 individuals, 205 exited in 2013, 22 in 2014, 31 in 2015, 45 in 2016, and 63 in 2017. We 
conducted a series of $t$-tests to analyze whether these 366 individuals are different from those who have remained in the sample. As shown in Table 4, these early exits represent entrepreneurs who are younger, and have lower corruption willingness, smaller venture size, fewer prior venturing experiences, and fewer of them are foreigners.

\section{-------Insert Table 4 about here-------}

To account for potential sample selection bias, we took the next few steps to test Hypothesis 1 by adopting the Heckman two-stage regression approach (Heckman, 1978, 1979). First, we generated a dummy variable of survival, taking a value of 1 for those remaining 1,299 entrepreneurs and a value of 0 for the 366 entrepreneurs who dropped out of the sample before 2018. Then in a probit analysis, we regressed an entrepreneur's prior corruption willingness, age, gender, prior venturing experience, number of contacts, foreigner identity, and venture size and sales to predict the likelihood of venture survival. The results are summarized in Table 5. This analysis showed that sales, gender, venture size, prior venturing experience, and age are significantly related to survival. We then calculated the inverse Mill's ratio (IMR) and included it in the second-stage regressions to predict attitudinal change to corruption, using the reduced sample of remaining entrepreneurs (Hamilton \& Nickerson, 2003).

\section{-------Insert Table 5 about here--------}

Next, we used the one-to-one propensity score matching method to match the foreign entrepreneurs to the local entrepreneurs based on the following observed characteristics: gender, age, prior entrepreneurial experience, number of contacts, venture size, and sector. This step resulted in a reduced sample of 955 matched entrepreneurs, of which 529 are foreign entrepreneurs and 426 are local entrepreneurs. Those entrepreneurs unable to be matched were dropped from our analysis. We carried out covariate imbalance tests to assess the balance (i.e., comparability) of the key individual characteristics in the two matched groups of entrepreneurs. Table 6 summarizes the results and shows that there is no significant difference between the means of the variables used to match the foreign and local samples at the 0.05 level, indicating the comparability of the matched entrepreneurs.

\section{-------Insert Table 6 about here--------}

In the second step, we conducted difference-in-difference analysis using the matched entrepreneurs to estimate the differential impacts of oil shock on the corruption willingness of the two 
groups. Table 7 presents the matched difference-in-difference tests of Hypothesis 1 . In Model 1, we only included treatment effects of the foreign dummy, and the time effects of oil shock. The STATA program automatically generates the difference-in-difference variable. This variable has a positive coefficient (1.01) and significance at the 0.001 level. The R square of Model 1 is 0.22 . Model 2 adds all control variables. The main effect of the difference-in-difference variable remains positive and significant $(0.66 ; p<0.001)$, strongly supporting H1. The added control variables enhance the explanatory power of Model 2, increasing R square to 0.41 . The result shows a significantly greater positive impact of the oil price crisis on entrepreneurs' corruption willingness for foreign entrepreneurs than for local entrepreneurs.

\section{-------Insert Table 7 about here-------}

The robustness tests for the full sample, employing a panel regression model, are presented in Table 8 . Model 1 in Table 8 is the baseline model showing the effects of control variables. Corruption willingness is higher for entrepreneurs who are older, male, with more prior venturing experience, more business contacts, and a smaller venture. Industry controls are not significant. For the countrylevel factors, higher GDP growth rates have a positive relationship with entrepreneurs' corruption willingness, and industry shares as a percentage of GDP seem to reduce corruption willingness. The independent variables of oil shock and foreign identity are introduced into Model 2 in Table 8. The main effect of the oil shock shows a significant and positive impact on entrepreneurs' overall corruption willingness $(0.066, p<0.001)$. On average, entrepreneurs in our sample showed a higher level of corruption willingness in the post-shock period, compared with the pre-shock period. The foreign identity variable is negative and significant $(-0.324, p<0.001)$, showing that foreign entrepreneurs on average had a lower level of corruption willingness during the study period. Model 3 in Table 8 presents the significant positive interaction effect $(0.669, p<0.001)$ between foreign entrepreneurs and the oil prices crisis. Results in this model are consistent with Model 2 of Table 7 in which we can observe both positive and significant effects of the interaction term between foreign dummy and post-shock dummy, which shows strong support for H1. 
Figure 4 depicts the interaction effect of oil price shock and foreign identity based on Model 3 of Table 8 . The dashed line represents the corruption willingness of foreign entrepreneurs, the solid line representing local entrepreneurs. During the pre-shock period (period 0), the corruption willingness of foreign entrepreneurs is less than -0.4 . This dashed line rises quickly towards 0.2 in the post-shock period (period 1). By contrast, the solid line is quite flat with a starting value a little over 0.2 and an ending value a little below 0.2 . H1 is, therefore, fully supported ${ }^{1}$.

-------Insert Figure 4 about here-------

\title{
The CPI Difference
}

Table 9 presents the panel regression results for testing H2, which proposes that the CPI difference positively moderates the impact of oil prices shock on foreign entrepreneurs' corruption willingness. Model 2 in Table 9 shows that the coefficient of the CPI difference is negative and significant $(-0.443, p<0.001)$, meaning that overall those foreign entrepreneurs from home countries less corrupt than their host countries have significantly lower levels of corruption willingness than those coming from more corrupt home countries. The moderating effect of the CPI difference is tested in Model 3. The result shows that the CPI difference positively moderates the effect of oil price shock on entrepreneurs' corruption willingness $(0.772, p<0.001)$. The CPI difference amplifies the positive effect of oil price shock, meaning that oil shock has a stronger positive impact on the corruption willingness of foreign entrepreneurs from less corrupt home countries than those from more corrupt home countries. The findings provide strong support for $\mathrm{H}_{2}^{2}$.

\author{
-------Insert Table 9 about here-------
}

\footnotetext{
${ }^{1}$ In analyses not shown here, we used an alternative approach by splitting the sample into two subgroups: foreign entrepreneurs and local entrepreneurs. We reran regressions and then compared the coefficients and stand errors of the variable of oil price crisis for both subsamples. We conducted a slope difference test and found that these two slopes are significant different, further supporting $\mathrm{H} 1$.

${ }^{2}$ While Crisis X CPI difference is a symmetric interaction term, we consider the crisis variable as the independent variable and the CPI difference the moderator because our theoretical focus is on the effect of the crisis, with the CPI difference examining the within-group variance among foreign entrepreneurs. We thank an anonymous reviewer to suggesting this clarification.
} 
Figure 5 shows the interaction effect of corruption difference and oil price shock on foreign entrepreneurs' corruption willingness. The solid line and dashed line indicate the predicted values of corruption willingness of foreign entrepreneurs from more corrupt and less corrupt home countries respectively. Both lines are going upward, with the solid line rising slowly and the dashed line rising much more steeply. The figure shows that entrepreneurs from more corrupt home countries have higher corruption willingness (solid line is above the dash line). The solid line is rather flat indicating entrepreneurs from more corrupt home countries did not experience significant attitudinal changes to corruption after the oil price crisis. In contrast, foreign entrepreneurs from less corrupt home countries experienced a greater increase in attitudinal change to corruption during the oil price shock, supporting $\mathrm{H} 2^{3}$.

-------Insert Figure 5 about here-------

\section{Discussion}

A crisis presents a unique situation where several forces, including system justification, the LOF, and the crisis itself, jointly impact entrepreneurs. Our study examines how the 2014 oil price crisis triggered sudden changes in entrepreneurs' attitudes toward corruption, but these changes differed in extent between foreign and local entrepreneurs. Our analyses are based on a unique survey dataset collected from about 1,000 entrepreneurs, both foreign and local, in seven oil-producing Middle Eastern countries that were hit hard by the crisis. In the pre-shock period, local entrepreneurs were more willing to engage in corruption than foreign entrepreneurs. However, as a counterintuitive result, foreign entrepreneurs substantially increased their willingness to engage in corruption in the post-shock period to the extent that their attitudes converged with and even exceeded those of locals; no such changes were found among local entrepreneurs. Among foreign entrepreneurs, individuals

\footnotetext{
${ }^{3} \mathrm{We}$ also ran a split sample analysis as an alternative test of $\mathrm{H} 2$. We split the sample into the groups of foreign entrepreneurs from less corrupt countries $(\mathrm{CPI}=1)$ and those from more corrupt countries $(\mathrm{CPI}=0)$. We calculated the coefficients and standard errors of both subsamples, followed by a slope difference test which found two slopes to be statistically different. These alternative analyses provide additional support to H2. These analyses are now shown here due to space limits but are available upon request.
} 
from less corrupt home countries increased corruption willingness more than those from corrupt home countries.

Our study contributes to SJT in two ways. First, the crisis in our study provides a causal mechanism for triggering attitudinal change. Prior SJT research is ambivalent about why sometimes a disadvantaged group may justify the system, just like the advantaged group, whereas at other times the disadvantaged group does not support or even opposes the status quo (Jost, 2019). To overcome the motivational conflict for the disadvantaged group, a major external shock can be the most fitting force to trigger the change from not justifying the system to justifying the system. Our study extends SJT research by showing how a major economic crisis triggers attitudinal change in the disadvantaged group: foreign entrepreneurs. While SJT emphasizes the importance of uncertainty and threat, most empirical studies have been conducted in "normal" contexts in which racial, gender, and other social identities drive system justification. Our study extends these studies by highlighting the unique effects of a crisis on system justification (Levy et al., 2010; Milojev et al., 2015). A crisis here presents an acute, impactful, and even existential threat that actually creates more opportunities for system justification than a normal circumstance. A crisis is a catalyst for foreign entrepreneurs to overcome the motivational conflict, to unlearn old attitudes, and to adapt to a radically different post-crisis environment. A crisis, therefore, is an important event that drives the disadvantaged group to rethink and readjust their attitudes toward the existing system.

Second, this study extends SJT research by adding a new distinction to the existing advantaged/disadvantaged social categories. Prior SJT research revolves around a central interest in social justice by examining racial equality, gender equality, political ideologies, and so on (Jost et al., 2003; Jost, 2019). Our study highlights the status differences between local and foreign entrepreneurs, an important distinction because it can activate different system justifications pertaining to the specific issue of corruption. While SJT suggests that a crisis increases the chances that a disadvantaged group would embrace the dominant values and norms (Jost et al., 2004), we integrate this important insight with the LOF literature (Zaheer, 1995; Eden \& Miller, 2004) to show that in response to crisis-induced stress and uncertainty, foreign entrepreneurs are more liable to change attitudes as a result of justifying the status quo. More interestingly, our $\mathrm{H} 2$ suggests that foreignness is 
relative, and some foreign entrepreneurs experience a greater extent of attitudinal change than other foreign entrepreneurs, depending on their home countries imprints regarding corruption. Prior socialization in their home countries preconditions foreign entrepreneurs, sometimes constrains their cognitive adaptation to local norms (Fisman \& Miguel, 2007), and affects how they react to a crisis in the host environment. Therefore, the LOF can add both between-group and within-group variances not previously discussed in the SJT literature, thus expanding and enriching the scope of SJT research.

Our study enriches entrepreneurial resilience literature by examining the interplay of the crisis, attitudinal changes of entrepreneurs, and the institutional complexity such as corruption. A crisis can fundamentally change how an individual connects means and ends when analyzing and approaching the external environment. While prior studies of crisis and entrepreneurship have examined various aspects, such as resilience (Williams et al., 2017), crisis management (Smallbone et al., 2012; Davidsson \& Gordon, 2016), resources (De Carolis et al., 2007), and social capital (Salvato et al., 2020), studies that examine the direct effects of a crisis on cognitive characteristics such as attitudes of entrepreneurs are rare. Since attitudes often function as an important filter for information collecting and processing that can be highly selective, they are important antecedents to decision making (Bohner \& Dickel, 2011). While prior crisis-entrepreneurship research has focused on the resources, social capital, and knowledge aspects of entrepreneurs (Block, 2010; Bullough et al., 2014; Davidsson \& Gordon, 2016; Marino et al., 2008), our study complements them by analyzing variances in attitudinal changes, a novel but important dimension not previously examined. Our study fills this void by focusing on the effects of the crisis on attitudinal changes among entrepreneurs in different groups. As the institutional environment shapes the way entrepreneurs form their attitudes toward the norm, a crisis can complicate this relationship and engender significant changes.

This crisis-attitude connection is important to entrepreneurship research. While cognition is a central notion in entrepreneurship research, most studies examine the consequences of cognition rather than the antecedents that drive the formation and change of entrepreneurial cognition such as attitudes (Gregoire, Corbett, \& McMullen, 2011). We show that a crisis can powerfully influence the attitudes of foreign entrepreneurs. While an entrepreneur may have relatively stable knowledge sets and other resource endowments, their mindsets and attitudes may change depending on the 
circumstances (Bohner \& Dickel, 2011; Albarracin \& Shavitt, 2018), which in turn can affect business decision making. A crisis, therefore, can reshape individual entrepreneurs' cognition. This causal mechanism starts from an external, rare event like a crisis and can work on attitudes, providing an important and less examined pathway for understanding the antecedents of entrepreneurial cognition. In terms of its consequences, a crisis therefore may eliminate or reduce heterogeneity among entrepreneurs, in terms of how they think of and react to dominant social norms. While in pre-crisis period, foreign entrepreneurs have different attitudes than local entrepreneurs toward corruption, and their attitudes have converged with those of local entrepreneurs in post-crisis period. At a societal level, a crisis can strengthen social cohesion by orienting different individuals in the same way and emphasizing social unity or the interests of the whole (Meyer et al., 2020).

Future research can extend our study in several ways. First, future research may examine whether similar attitudinal changes happen to entrepreneurs, foreign or local, under different types of crises. Crises could be economic like the oil crisis we have examined, natural crises like the tsunami in Indonesia in 2004, or a biological crisis like COVID-19, and so on. Different crises have specific effects and mechanisms that may influence entrepreneurs in different ways. Second, future research can examine the long-term implications of such economic shocks on entrepreneurs. Third, one interesting result concerns the corruption willingness of local entrepreneurs who on average show a slight (although not significant) decrease of their attitudes ${ }^{4}$. This decrease of corruption willingness among local entrepreneurs could result from 1) the anti-corruption campaigns launched by local governments in mitigating corruption incidents; or 2) the wide adoption of digital technologies among these Middle Eastern countries is transforming how people interact in societies, which is changing social fabrics including social norms such as corruption. To explore this interesting result is beyond the scope of this study but definitely merits future research attention.

Our study is limited in a few respects. First, future research may expand the sample of foreign entrepreneurs to include some foreign entrepreneurs working in less corrupt host countries such as the

\footnotetext{
${ }^{4}$ We appreciate the comments of an anonymous reviewer in suggesting future research on this interesting result.
} 
UK, US, or others. It is possible that some foreign entrepreneurs who chose to go to the Middle East already had a higher tolerance for corruption. This potential issue of self-selection may influence the variance among foreign entrepreneurs in the sample. Second, while our study utilizes an interesting context of the 2014 oil price shock, future research using other contexts or crises would strengthen the generalizability of findings reported in this study. Third, our sample only used sole proprietors and did not include other types of entrepreneurs such as incorporated firms or ventures with more owners/founders. Sole proprietors are just one type of entrepreneurs, even though they are relevant in the contexts of our study of the Middle East. Other types of entrepreneurs such as high-impact entrepreneurs (Henrekson \& Sanandaji, 2014; 2020) may become interesting subjects of study for the future. This limitation results from the data collection procedure and limits the external validity of our study. Future research may consider including more diverse entrepreneurs and venture firms. Last, future studies could also control for the number of years of entrepreneurs in operation to account for familiarity with the environment, which might be particularly important for foreign entrepreneurs.

In conclusion, our study uses a unique natural experiment of 2014 oil price shock to examine how entrepreneurs in the Middle East change their attitudes toward corruption differently. We show that foreign entrepreneurs have changed their attitudes significantly due to the crisis, compared with local entrepreneurs, and such attitudinal change is moderated by corruption distance between the home-host country dyad. 


\section{References}

Agbo, A., \& Iwundu, EI. (2016). Corruption as a propensity: Personality and motivational determinants among Nigerians. Journal of Psychology, 150(4), 502-526.

Albarracin, D., \& Shavitt, S. (2018). Attitudes and attitude change. Annual Review of Psychology, 69, 299-327.

Alvarez, S., \& Barney, J. (2020). Insights from creation theory: The uncertain context rendered by the Covid-19 pandemic. Strategic Entrepreneurship Journal, forthcoming.

Baron, R., \& Ward, T. (2004). Expanding entrepreneurial cognition's toolbox: Potential contributions from the field of cognitive science. Entrepreneurship Theory and Practice, 28(6): 553-573.

Beaman, L., Duflo, E., Pande, R., \& Topalova, P. (2012). Female leadership raises aspirations and educational attainment for girls: A policy experiment in India. Science, 335(6068), 582-586.

Block, J. (2010). Family management, family ownership and downsizing: Evidence from S\&P 500 firms. Family Business Review, 23(2): 109-130.

Bohner, G., \& Dickel, N. (2011). Attitudes and attitude change. Annual Review of Psychology, 62, 391-417.

Brannon, L., Tagler, M., \& Eagly. (2007). The moderating role of attitude strength in selective exposure to information. Journal of Experimental Social Psychology, 43(4), 611-617.

Budak J \& Rajh E (2014.) Corruption as an obstacle for doing business in the Western Balkans: A business sector perspective. International Small Business Journal, 32(2), 140-157.

Bullough, A., Renko, M., \& Myatt, T. (2014). Danger zone entrepreneurs: The importance of resilience and self-efficacy for entrepreneurial intentions. Entrepreneurship Theory and Practice, 38(3), 473-499.

Chirico, F., Gomez-Mejia, L., Hellerstedt, K., Withers, M., \& Nordqvist, M. (2019). To merge, sell, or liquidate? Socioemotional wealth, family control, and the choice of business exit. Journal of Management, https://doi.org/10.1177/0149206318818723.

Cowling, M., Liu, W. \& Ledger, A. (2012). Small business financing in the UK before and during the current financial crisis. International Small Business Journal, 30(7), 778-800. https://doi.org/10.1177/0266242611435516

Cull, R., \& Xu, L. (2005). Institutions, ownership, and finance: the determinants of profit reinvestment among Chinese firms. Journal of Financial Economics, 77(1), 117-146.

Davidsson, P., \& Gordon, S. (2016). Much ado about nothing? The surprising persistence of nascent entrepreneurs through macroeconomic crisis. Entrepreneurship Theory and Practice, 40, (4), 915-941.

De Carolis, D., Yang, Y., Deeds, D., \& Nelling, E. (2009). Weathering the storm: The benefit of resources to hightechnology ventures navigating adverse events. Strategic Entrepreneurship Journal, 3, 147-160.

Dickel, P., \& Graeff, P. (2018). Entrepreneurs' propensity for corruption: A vignette-based factorial survey. Journal of Business Research, 89, 77-86.

Doern, R. (2016). Entrepreneurship and crisis management: The experiences of small businesses during the London 2011 riots. International Small Business Journal, 34(3), 276-302. https://doi.org/10.1177/0266242614553863

Doern, R., Williams, N., \& Vorley, T. (2019) Special issue on entrepreneurship and crisis: Business as usual? An introduction and review of the literature. Entrepreneurship and Regional Development, 31(5-6), 400-412.

Ellyatt, H. 2016. Middle East prepares for a post-oil era. Retrieved from: https://www.cnbc.com/2016/01/22/the-middle-eastafter-oil.html

Ernst \& Young, 2014. Bribery, corruption, and fraud in the Middle East. www.ey.com/mena/

Fisman, R., \& Miguel, E. (2007) Corruption, norms, and legal enforcement: Evidence from diplomatic parking tickets. Journal of Political Economy 115(6): 1020-1048.

Friesen, J. P., Laurin, K., Shepherd, S., Gaucher, D., \& Kay, A. C. (2019). System justification: Experimental evidence, its contextual nature, and implications for social change. British Journal of Social Psychology, 58, 315-339.

Godinez, J., \& Liu, L. (2015) Corruption distance and FDI flows into Latin America. International Business Review, 24(1), $33-42$.

Gregoire, D., Corbett, A., \& McMullen, J. (2011). The cognitive perspective in entrepreneurship: An agenda for future research. Journal of Management Studies, 48(6), 1443-1477.

Grube, L. E. \& V.H. Storr. (2018). Embedded entrepreneurs and post-disaster community recovery. Entrepreneurship and Regional Development, 30(1), 7-8. https://doi.org/10.1080/08985626.2018.1457084

Habib, M., \& Zurawicki, L. (2002). Corruption and foreign direct investment. Journal of International Business Studies, 33(2), 291-307.

Hafez, Z. (2009). The culture of rent, factionalism, and corruption: a political economy of rent in the Arab World. Contemporary Arab Affairs, 2(3), 458-480.

Hamilton, B., \& Nickerson, J. (2003). Correcting for endogeneity in strategic management research. Strategic Organization, $1(1), 51-78$.

Heckman, J. (1978). Dummy endogenous variables in a simultaneous equations system. Econometrica, 46, 931-960.

Heckman, J. (1979). Sample selection bias as a specification error. Econometrica, 47, 153-162.

Henrekson, M., \& Sanandaji, T. (2014). Small business activity does not measure entrepreneurship. Proceedings of the National Academy of Sciences, 111(5), 1760-1765.

Henrekson, M., \& Sanandaji, T. (2020). Measuring Entrepreneurship: Do Established Metrics Capture Schumpeterian Entrepreneurship? Entrepreneurship Theory and Practice, 44(4), 733-760.

Hmieleski, K., Corbett, A., \& Baron, R. (2013). Entrepreneurs' improvisational behavior and firm performance: A study of dispositional and environmental moderators. Strategic Entrepreneurship Journal, 7, 138-150.

Hou, Keane, Kennan, \& Velde, 2015. The oil price shock of 2014. Working paper. Retrieved from: https://www.odi.org/sites/odi.org.uk/files/odi-assets/publications-opinion-files/9589.pdf 
Iriyama, A., Kishore, R., \& Talukdar, D. (2016). Playing dirty or building capability? Corruption and HR training as competitive actions to threats from informal and foreign firm rivals. Strategic Management Journal, 37(10), 21522173.

James, E., Wooten, L., \& Dushek, K. (2011). Crisis management: Informing a new leadership research agenda. Academy of Management Annals, 5(1): 455-493.

Jost, J. (2019). A quarter century of system justification theory: Questions, answers, criticisms, and societal applications. British Journal of Social Psychology, 58: 263-314.

Jost, J., \& Banaji, M. (1994). The role of stereotyping in system-justification and the production of false consciousness. British Journal of Social Psychology, 33: 1-27.

Jost, J., \& Hunyady, O. (2002). The psychology of system justification and the palliative function of ideology. European Review of Social Psychology, 13, 111-153.

Jost, J., \& Hunyady, O. (2005). Antecedents and consequences of system-justifying ideologies. Current Directions in Psychological Science, 14 (5): https://doi.org/10.1111/j.0963-7214.2005.00377.x

Jost, J., Banaji, M., \& Nosek, B., (2004). A decade of system justification theory: Accumulated evidence of conscious and unconscious bolstering of the status quo. Political Psychology, 25(6): 881-919.

Jost, J., Liviatan, I., van der Toorn, J., Ledgerwood, A., Mandisodza, A., \& Nosek, B. (2012). System justification: A motivational process with implications for social conflict. Eds, Kals, E., \& Maes, J, Justice and Conflicts. SpringerVerlag Berlin Heidelberg. DOI 10.1007/978-3-642-19035-3_19

Kay, A., \& Zanna, M. (2009). A contextual analysis of the system justification motive and its societal consequences. J. T. Jost, A.C. Kay, \& H. Thorisdottir (Eds). Series in political psychology. Social and psychological bases of ideology and system justification. Oxford University Press.

Kauffman Foundation. (2014). The economic case for welcoming immigrant entrepreneurs. Retrieved from https://www.kauffman.org/wpcontent/uploads/2019/12/the economic case for welcoming immigrant entrepreneurs updated september 2015.pdf

Kilian, L. (2015). Why did the price of oil fall after June 2014? Retrieved from https://voxeu.org/article/causes-2014-oilprice-decline

Knight, G., \& Cavusgil, S. (2004). Innovation, organizational capabilities, and the born-global firm. Journal of International Business Studies, 35(4),334-334.

Kulchina, E. (2016). A path to value creation for foreign entrepreneurs. Strategic Management Journal, 37, 1240-1262.

Kulchina, E. (2017). Do foreign entrepreneurs benefit their firms as managers? Strategic Management Journal, 38, 15881607.

Levy, S., Freitas, A., Mendoza-Denton, R., Kugelmass, H., \& Rosenthal, L. (2010). When sociopolitical events strike cultural beliefs: Divergent impact of Hurricane Katrina on African Americans' and European Americans' endorsement of the protestant work ethic. Basic and Applied Social Psychology, 32,207-216.

Liu, K., Al Asady, A., \& Fu, K. (2020). How do foreign entrepreneurs adapt to local corruption norms in the Middle East? Institutional multiplicities and individual adaptation. International Small Business Journal, 38, 629-653.

Marino, L., Lohrke, F., Hill, J., Weaver, K., \& Tambunan, T. (2008). Environmental shocks and SME alliance formation intentions in an emerging economy: Evidence from the Asian financial crisis in Indonesia. Entrepreneurship and Theory Practice, 32(1), 157-183.

McMullen, J., \& Kier, A. (2016). Trapped by the entrepreneurial mindset: Opportunity seeking and escalation of commitment in the Mount Everest disaster. Journal of Business Venturing, 31, 663-686.

Merriman, M. (2020). Beyond COVID-19: How a crisis shifts cultural and societal behaviors. Retrieved from: https://www.ey.com/en us/consulting/beyond-covid-19-how-a-crisis-shifts-cultural-and-societal-behaviors

Meyer, K., Pedersen, C., \& Ritter, T. (2020). The coronavirus crisis: A catalyst for entrepreneurship. Retrieved from https://theconversation.com/the-coronavirus-crisis-a-catalyst-for-entrepreneurship-135005

Miller, D., Steier, L., \& Breton-Miller, I. (2016). What can scholars of entrepreneurship learn from sound family businesses. Entrepreneurship Theory and Practice, 40(3), 445-455.

Moffit, R., Fitzgerald, J., \& Gottschalk, P. (1999). Sample attrition in panel data: The role of selection on observables. Annales d'Economie et de Statistique, 55/56, 129-152.

Mohammadian-Molina, R. (2020). The changing face of business in the Middle East. Retrieved from: https://www.entrepreneur.com/article/346429

Odeh, A., \& Sahlawi, Y. (2020). Local partner share contribution in the UAE: What you need to know. Retrieved from https://legaladviceme.com/legal-blog/174/local-partner-share-contribution-in-uae-what-you-need-to-know

Osborne, D., Sengupta, N., \& Sibley, C. G. (2019). System justification theory at 25: Evaluating aparadigm shift in psychology and looking towards the future. British Journal of Social Psychology, 58, 340-361.

Pandis N. 2016. Using linear regression for $t$ tests and analysis of variance. American Journal of Orgodontics \& Dentofacial Orthopedics, 149(5): 769.

Parker, S. C., Congregado, E. \& A.A. Golpe. (2012). "Testing for hysteresis in entrepreneurship in 23 OECD countries." Applied Economics Letters, 19(1): 61-66. https://doi.org/10.1080/13504851.2011.566175

Pearson C.M. \& J.A. Clair. (1998). "Reframing crisis management." Academy of Management Review, 23(1): 59-76. https://www.jstor.org/stable/259099

Reise, SP., Ventura, J., Nuechterlein, KH., \& Kim, K. (2005). An illustration of multilevel factor analysis. Journal of Personality Assessment, 84(2),126-136. 
Salvato, C., Sargiacomo, M., Amore, M., \& Minichilli, A. (2020) Natural disasters as a source of entrepreneurial opportunity: Family business resilience after an earthquake. Strategic Entrepreneurship Journal, forthcoming.

Sieweke, J., \& Santoni, S. (2020). Natural experiments in leadership research: An introduction, review, and guidelines. Leadership Quarterly, 31, 1-25.

Smallbone, D., Deakins, D., Battisti, M. \& J. Kitching. (2012). "Small business responses to a major economic downturn: Empirical perspectives from New Zealand and the United Kingdom." International Small Business Journal, 30(7), 754-777. https://doi.org/10.1177/0266242612448077

Stuart, E.A., Huskamp, H.A., Duckworth, K., Simmons, J., Song, Z., Chernew, M.E. and Barry, C.L., 2014. Using propensity scores in difference-in-differences models to estimate the effects of a policy change. Health Services and Outcomes Research Methodology, 14(4), pp.166-182.

Toft-Kehler, R., Wennberg, K., \& Kim, P. (2014). Practice makes perfect: Entrepreneurial-experience curves and venture performance. Journal of Business Venturing, 29(4), 453-470.

Tomass, M. (2012). Religious identity, informal institutions, and the nation-states of the Near East. Journal of Economic Issues, 46(3), 705-728.

Touati, K. (2014). Determinants of Economic Corruption in the Arab Countries: Dangers and Remedies. Journal of Economics Studies and Research, 1-15.

Van der Toorn, J., \& Jost, J.T. (2014). Twenty years of system justification theory: Introduction to the special issue on "Ideology and system justification processes". Group Processes \& Intergroup Relations, 17(4): 413-419.

Von Dawans, B., Fischbacher, U., Kirschbaum, C., Fehr, E., \& Heinrichs, M. (2012). The social dimension of stress reactivity: Acute stress increases prosocial behavior in humans. Psychological Science, 23(6): 651-660.

Wakslak, C. J., Jost, J. T., \& Bauer, P. (2011). Spreading rationalization: Increased support for large-scale and small-scale social systems following system threat. Social Cognition, 29, 288-302. doi:10.1521/soco.2011.29.3.288

Weick, K. (1993). The collapse of sensemaking in organizations: The Mann Gulch disaster. Administrative Science Quarterly, 38(4), 628-652.

Weick, K. (1996). Drop your tools: An allegory for organizational studies. Administrative Science Quarterly, 41(2), 301313.

Williams, T.A. \& Shepherd. D. (2016). Building Resilience or Providing Sustenance: Different Paths of Emergent Ventures in the Aftermath of the Haiti Earthquake. Academy of Management Journal, 59(6): 2069-2102. https://doi.org/10.5465/amj.2015.0682

Williams, N., \& Vorley, T. (2015). The impact of institutional change on entrepreneurship in a crisis-hit economy: The case of Greece. Entrepreneurship and Regional Development, 27(1-2): 28-49. https://doi.org/10.1080/08985626.2014.995723

Williams, T.A. D.A. Gruber, K.M. Sutcliffe, D.A. Shepherd, and E.Y. Zhao. (2017). Organizational Response to Adversity: Fusing Crisis Management and Resilience Research Streams. Academy of Management Annals, 11(2), 733-769. https://doi.org/10.5465/annals.2015.0134

Zaheer, S. (1995). Overcoming the liability of foreignness. Academy of Management Journal, 38(2), 341-363. 
1 I believe the level of government corruption in the country I'm operating in is low.

2 I believe that engaging in corruption in a corrupt environment does not give me advantage over my competition.

3 Paying bribes to other individuals is morally wrong, even if I make a profit.

4 I do not engage in corruption in my home country.

5 I believe that corruption does not add value to my business and it does not increase my profits.

6 I rarely entice persons of interest with payments to secure worthwhile business contracts.

7 I believe that the laws and policies in my current environment hinder my ability to engage in corruption to maximize my profits.

8 I avoid pursuing corrupt opportunities to maximize my profits.

9 I rarely establish corrupt industry contacts so that I may exploit corrupt opportunities.

10 I seldom gauge people's propensity to engage in corruption through disclosure of possible profits of potential corrupt deals

11 I seldom exploit people's willingness to increase their personal income by accentuating the potential income from corrupt opportunities.
1234567 I believe the level of government corruption in the country I'm operating in is high.

1234567 I believe that engaging in corruption in a corrupt environment gives me advantage over my competition.

1234567 Paying bribes to other individuals is morally acceptable, especially if I make a profit.

1234567 I engage in corruption in my home country.

1234567 I believe that corruption adds value to my business and it does increase my profits.

1234567 I actively entice persons of interest with payments to secure worthwhile business contracts.

1234567 I believe that the laws and policies in my current environment aid my ability to engage in corruption to maximize my profits.

1234567 I actively pursue corrupt opportunities to maximize my profits.

1234567 I constantly establish corrupt industry contacts so that I may exploit future corrupt opportunities.

1234567 I actively gauge people's propensity to engage in corruption through the disclosure of possible profits of potential corrupt deals.

1234567 I actively exploit people's willingness to increase their personal income by accentuating the potential income from corrupt opportunities. 
Figure 1. Historical oil prices between 2010 and 2018

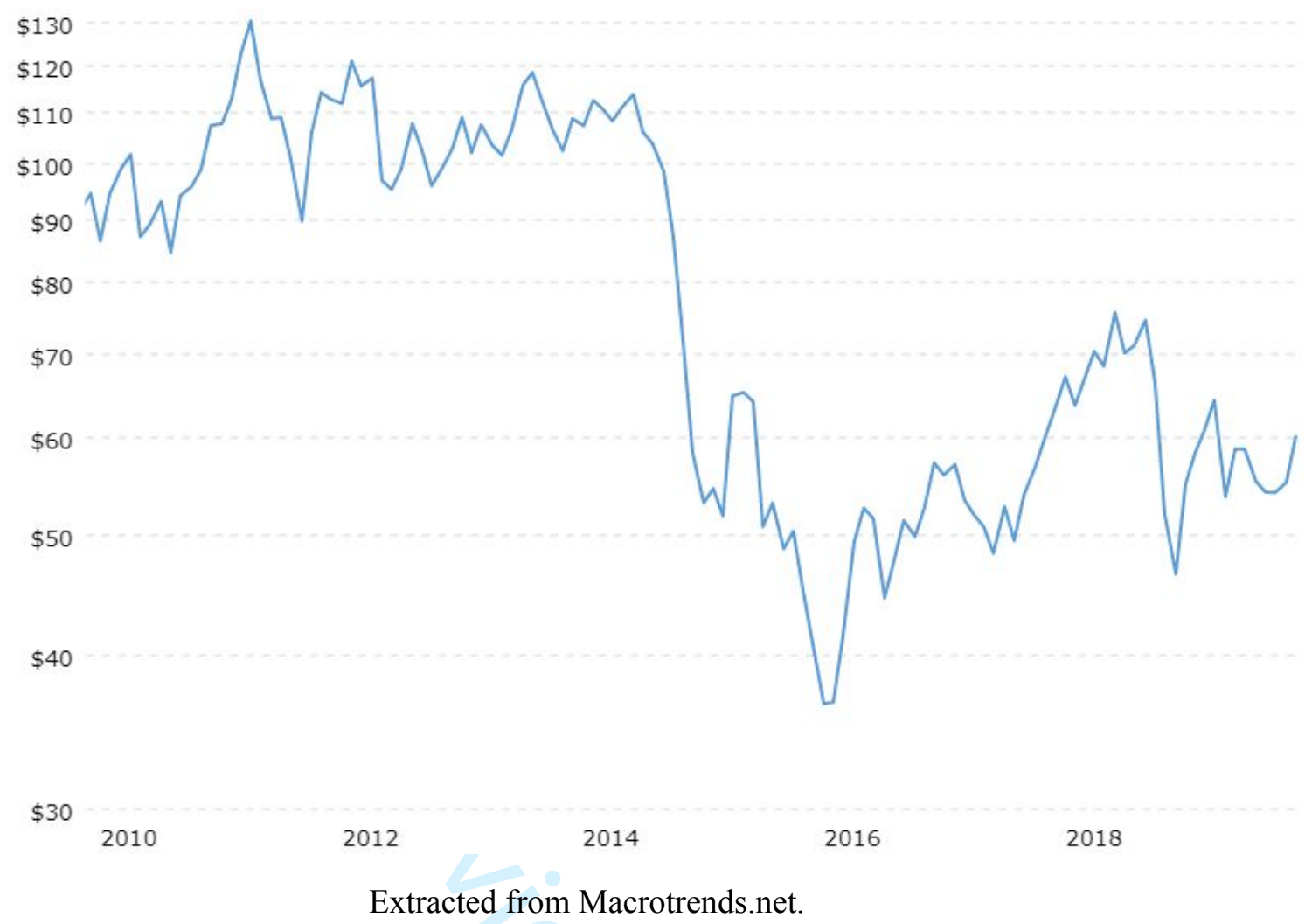

Figure 2. Distribution of Entrepreneurs in the Host Countries in 2013

\section{Distribution of foreign and local entrepreneurs in seven countries}

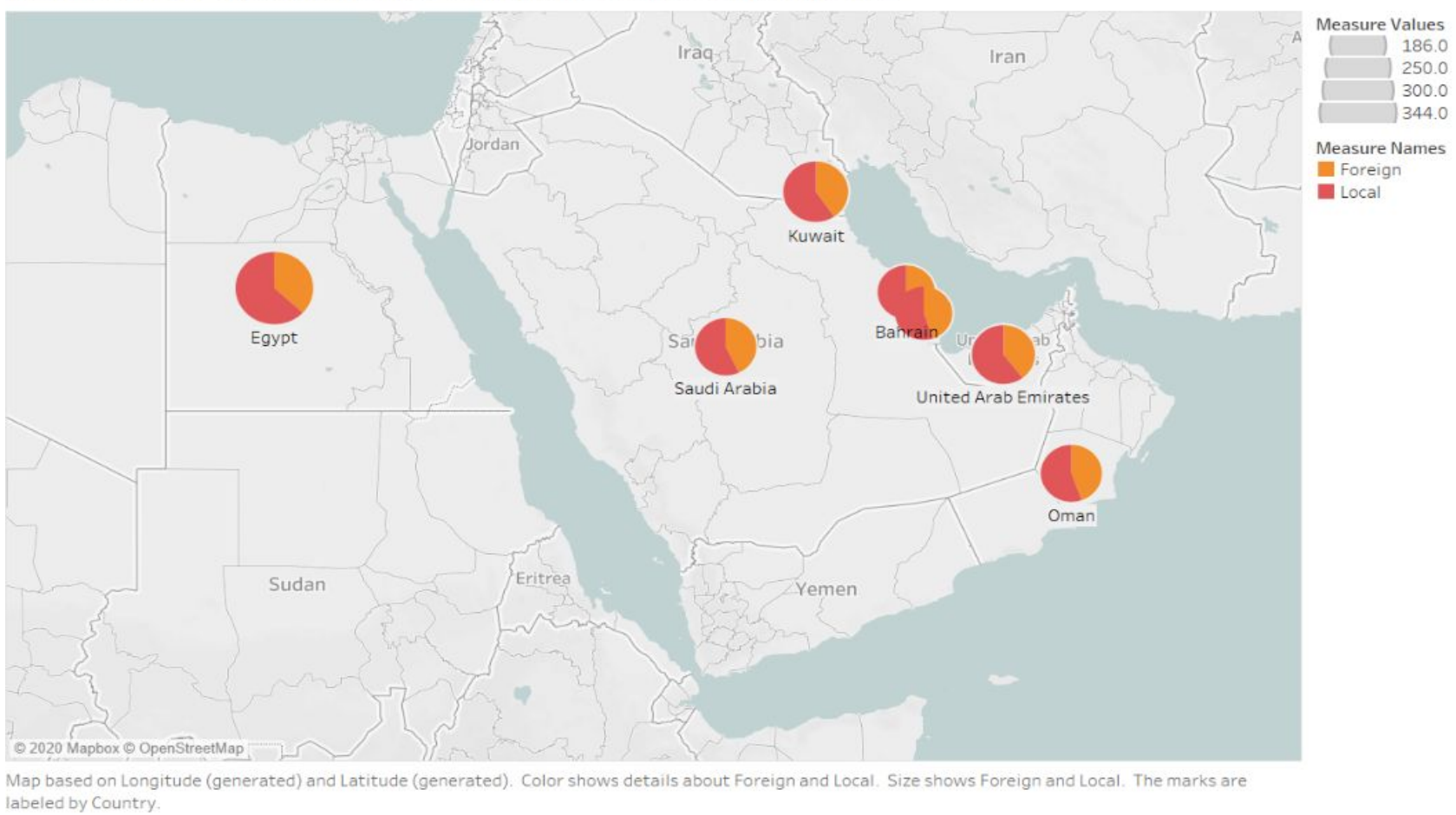


Figure 3. The Trend of Corruption Willingness: Foreign versus Local Entrepreneurs

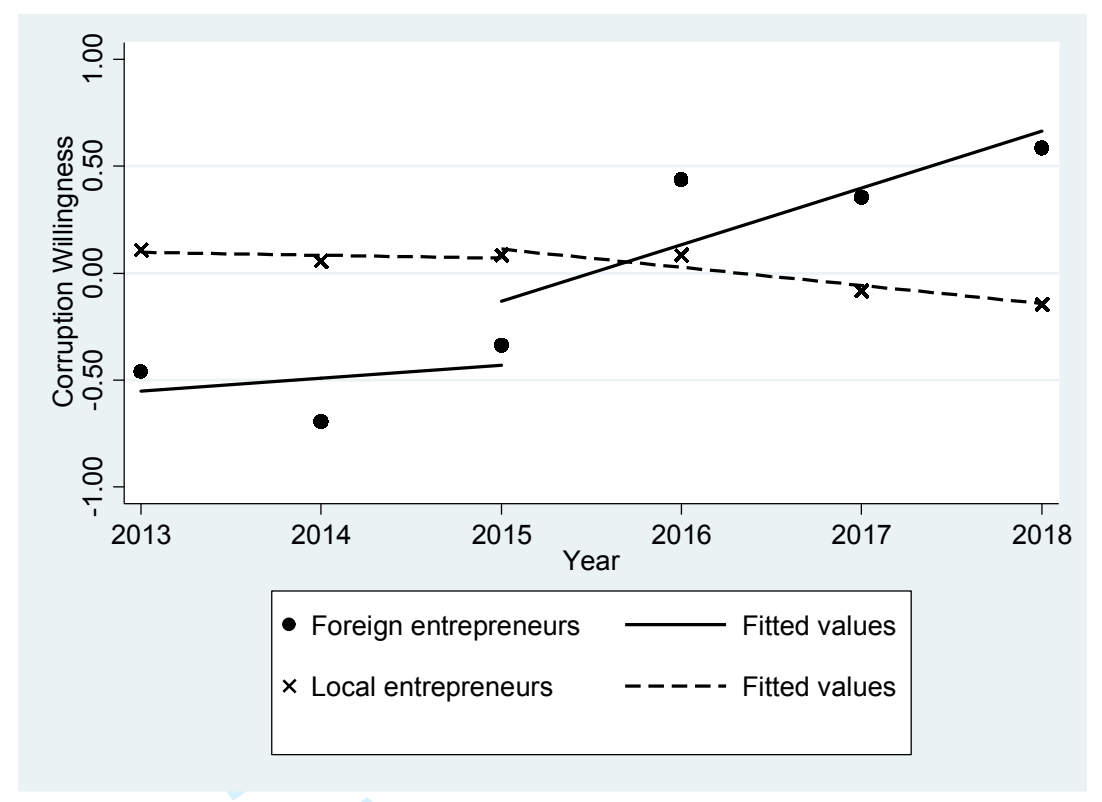

Figure 4. Influences of Oil Price Crisis on Entrepreneurs' Corruption Willingness

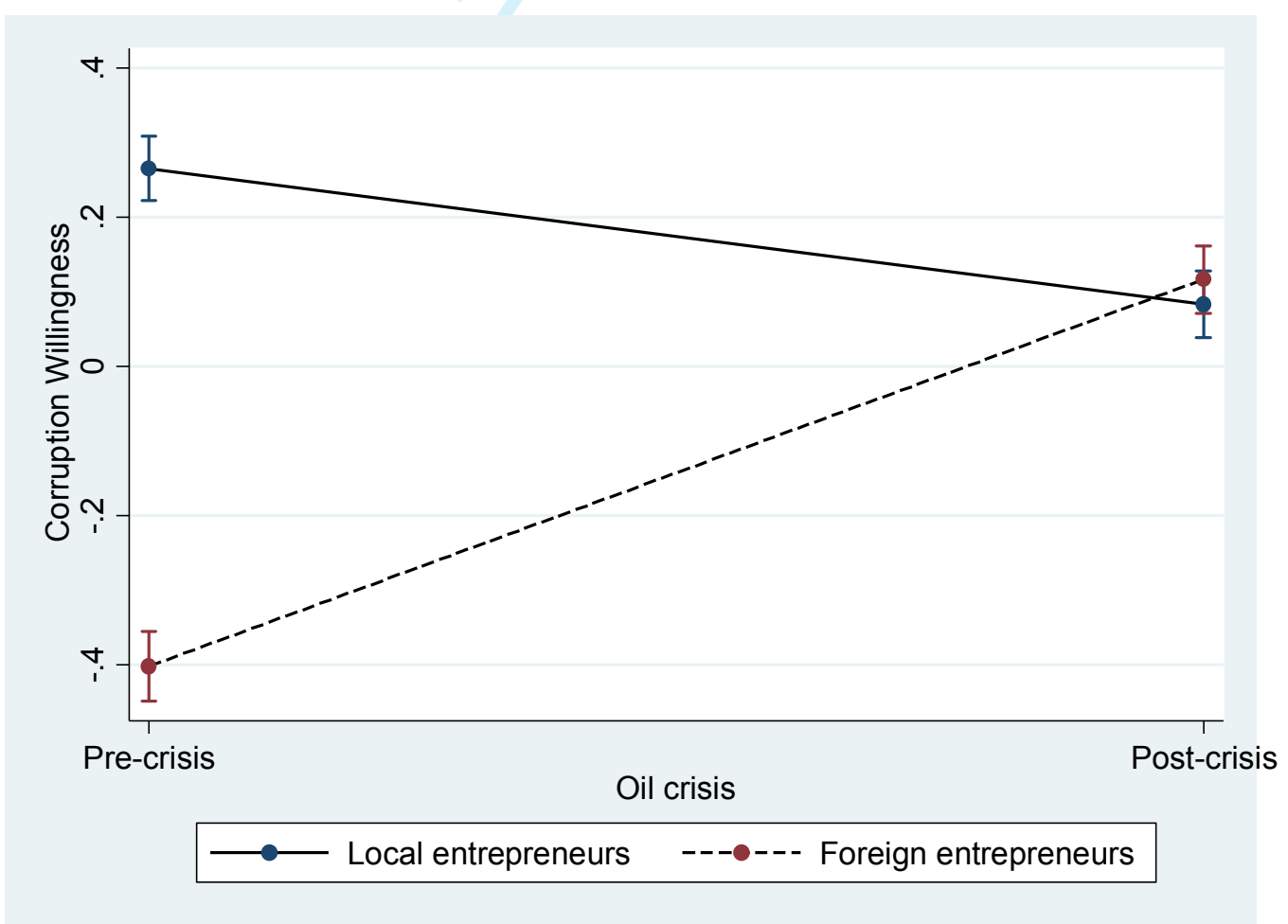


Figures 5. CPI Difference Moderating the Relationship between Oil Shock and Corruption Willingness

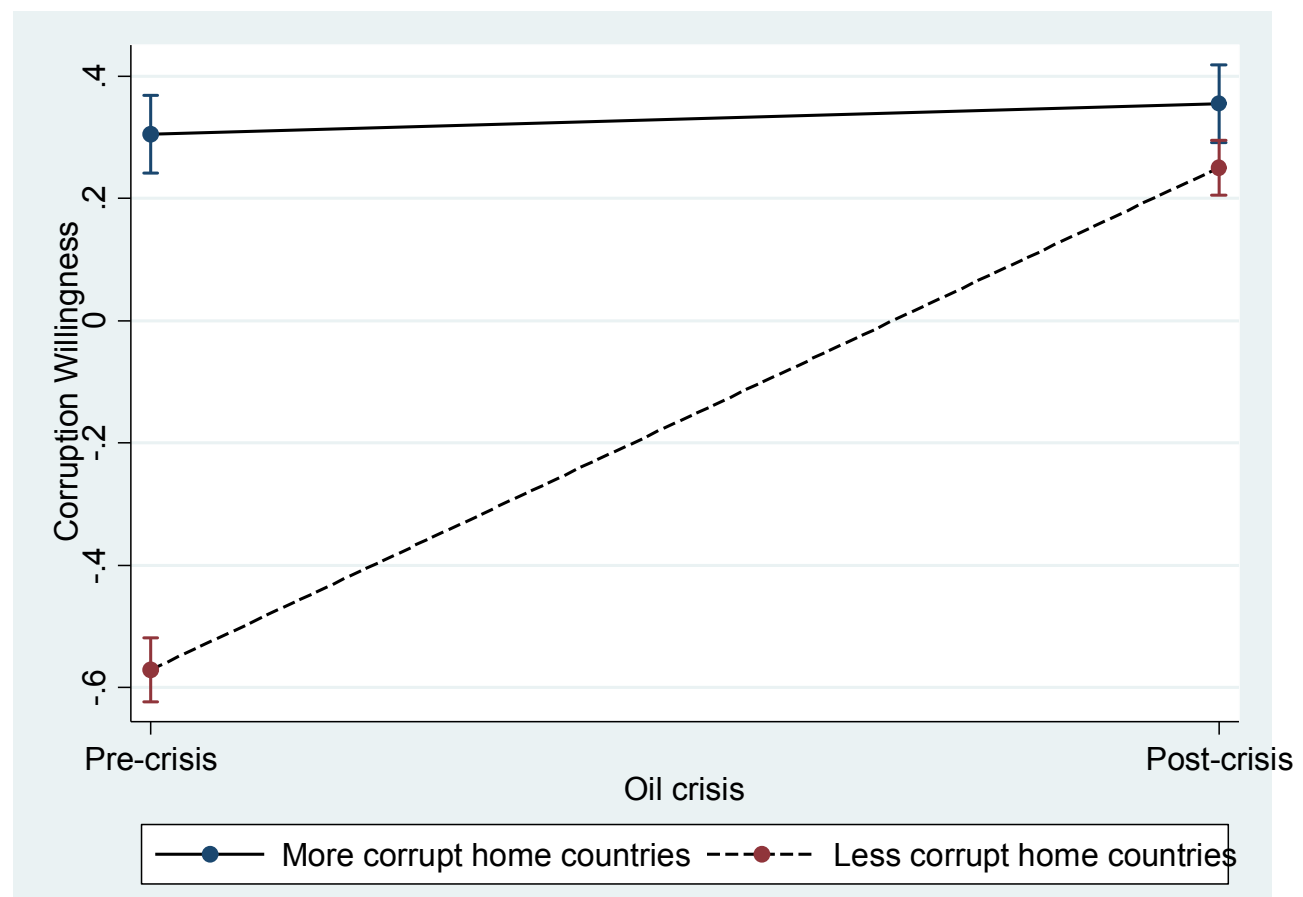


Table 1. Distribution of foreign entrepreneurs based on home countries

\begin{tabular}{|c|c|c|}
\hline Home Country & Percentage & Number \\
\hline Algeria & $0.30 \%$ & 2 \\
\hline Australia & $8.19 \%$ & 64 \\
\hline Brazil & $0.40 \%$ & 3 \\
\hline Canada & $3.84 \%$ & 30 \\
\hline Chad & $0.30 \%$ & 2 \\
\hline China & $3.44 \%$ & 27 \\
\hline Colombia & $0.30 \%$ & 2 \\
\hline Cyprus & $0.61 \%$ & 5 \\
\hline Czech Republic & $0.10 \%$ & 1 \\
\hline Denmark & $0.91 \%$ & 7 \\
\hline Egypt & $2.12 \%$ & 16 \\
\hline Finland & $3.24 \%$ & 25 \\
\hline France & $1.82 \%$ & 14 \\
\hline Georgia & $0.30 \%$ & 2 \\
\hline Germany & $5.56 \%$ & 43 \\
\hline Greece & $2.93 \%$ & 23 \\
\hline Hong Kong & $0.71 \%$ & 6 \\
\hline Hungary & $0.10 \%$ & 1 \\
\hline India & $17.29 \%$ & 134 \\
\hline Iran & $0.10 \%$ & 1 \\
\hline Ireland & $1.82 \%$ & 14 \\
\hline Italy & $0.10 \%$ & 1 \\
\hline Japan & $0.20 \%$ & 2 \\
\hline KSA & $0.20 \%$ & 2 \\
\hline Kazakhstan & $0.10 \%$ & 1 \\
\hline Kenya & $0.61 \%$ & 5 \\
\hline Korea & $0.51 \%$ & 4 \\
\hline Kuwait & $0.10 \%$ & 1 \\
\hline Libya & $0.81 \%$ & 6 \\
\hline Lithuania & $0.30 \%$ & 2 \\
\hline Macedonia & $0.10 \%$ & 1 \\
\hline Malaysia & $0.10 \%$ & 1 \\
\hline New Zealand & $0.91 \%$ & 7 \\
\hline Nigeria & $0.10 \%$ & 1 \\
\hline Norway & $2.22 \%$ & 17 \\
\hline Oman & $0.51 \%$ & 4 \\
\hline Pakistan & $0.30 \%$ & 2 \\
\hline Poland & $0.30 \%$ & 2 \\
\hline Portugal & $0.30 \%$ & 2 \\
\hline Qatar & $3.24 \%$ & 25 \\
\hline Romania & $0.51 \%$ & 4 \\
\hline Russia & $0.61 \%$ & 5 \\
\hline
\end{tabular}




\begin{tabular}{lrr} 
Scotland & $0.10 \%$ & 1 \\
Senegal & $2.63 \%$ & 20 \\
Serbia & $0.10 \%$ & 1 \\
Slovakia & $0.20 \%$ & 2 \\
Slovenia & $0.40 \%$ & 3 \\
Somalia & $0.40 \%$ & 3 \\
South Africa & $1.52 \%$ & 12 \\
Spain & $0.40 \%$ & 3 \\
Sudan & $0.40 \%$ & 3 \\
Sweden & $1.72 \%$ & 13 \\
Switzerland & $2.73 \%$ & 21 \\
Syria & $1.11 \%$ & 9 \\
Tunisia & $0.30 \%$ & 2 \\
Turkey & $2.43 \%$ & 19 \\
UAE & $3.13 \%$ & 24 \\
U.K. & $11.12 \%$ & 86 \\
USA & $4.65 \%$ & 36 \\
Ukraine & $0.10 \%$ & 1 \\
\hline Total & & 777 \\
\hline
\end{tabular}


Table 2a. Descriptive Statistics (Full Sample)

\begin{tabular}{lccccc}
\hline Variable & Observation & Mean & Std. Dev. & Min & Max \\
\hline Corruption willingness & 7,857 & 0.03 & 0.96 & -2.80 & 2.02 \\
Oil price shock & 7,857 & 0.49 & 0.50 & 0 & 1 \\
Foreign & 7,857 & 0.50 & 0.50 & 0 & 1 \\
Gender & 7,857 & 0.74 & 0.44 & 0 & 1 \\
Age group & 7,857 & 2.35 & 1.10 & 1 & 5 \\
Prior entrepreneurial experience & 7,857 & 2.37 & 1.67 & 0 & 11 \\
Number of contacts & 7,857 & 9.19 & 5.84 & 0 & 29 \\
Venture size & 7,857 & 5.83 & 2.80 & 1 & 16 \\
Sector & 7,857 & 3.88 & 1.85 & 1 & 7 \\
GDP growth & 7,857 & -0.07 & 2.44 & -5.84 & 4.51 \\
Industry share (\% of GDP) & 7,857 & 2.08 & 0.93 & 0.1 & 3.6 \\
Host country & 7,857 & 4.01 & 2.01 & 1 & 7 \\
\hline
\end{tabular}

Table 2b. Descriptive Statistics (Foreign Entrepreneur Sample)

\begin{tabular}{lccccc}
\hline Variable & Observation & Mean & Std. Dev. & Min & Max \\
\hline Corruption willingness & 3,948 & -0.002 & 0.96 & -2.8 & 2.02 \\
Oil price shock & 3,948 & 0.68 & 0.47 & 0 & 1 \\
CPI difference & 3,948 & 0.70 & 0.46 & 0 & 1 \\
Age group & 3,948 & 2.31 & 1.15 & 1 & 5 \\
Gender & 3,948 & 0.86 & 0.34 & 0 & 1 \\
Prior entrepreneurial experience & 3,948 & 2.98 & 1.73 & 0 & 11 \\
Number of contacts & 3,948 & 11.42 & 6.24 & 0 & 29 \\
Venture size & 3,948 & 6.94 & 2.67 & 4 & 16 \\
Sector & 3,948 & 3.86 & 1.86 & 1 & 7 \\
GDP growth & 3,948 & -0.3 & 2.5 & -5.84 & 4.51 \\
Industry share (\% of GDP) & 3,948 & 2.06 & 0.93 & 0.1 & 3.6 \\
Host country & 3,948 & 4 & 1.95 & 1 & 7 \\
\hline
\end{tabular}


Table 3a. Correlations of Variables (Full sample)

\begin{tabular}{|c|c|c|c|c|c|c|c|c|c|c|c|c|c|c|c|}
\hline & & 1 & 2 & 3 & 4 & 5 & 6 & 7 & 8 & 9 & 10 & 11 & 12 & 13 & 14 \\
\hline 1 & Corruption willingness & 1 & & & & & & & & & & & & & \\
\hline 2 & Oil price shock & $0.22 *$ & 1 & & & & & & & & & & & & \\
\hline 3 & Foreign & $-0.03 *$ & $0.06^{*}$ & 1 & & & & & & & & & & & \\
\hline 4 & Gender & $0.37 *$ & 0.01 & $0.28 *$ & 1 & & & & & & & & & & \\
\hline 5 & Age group (28-37) & $-0.03 *$ & $0.07 *$ & $-0.07 *$ & $-0.03 *$ & 1 & & & & & & & & & \\
\hline 6 & Age group (38-47) & $-0.09 *$ & 0.005 & $-0.08^{*}$ & $-0.07 *$ & $-0.39 *$ & 1 & & & & & & & & \\
\hline 7 & Age group (48-57) & $0.06^{*}$ & $0.04 *$ & $0.04 *$ & $0.05^{*}$ & $-0.31 *$ & $-0.22 *$ & 1 & & & & & & & \\
\hline 8 & Age group (58-67) & $0.04 *$ & $0.10 *$ & 0.01 & 0.01 & $-0.12 *$ & $-0.09 *$ & $-0.07 *$ & 1 & & & & & & \\
\hline 9 & Prior entrepreneurial experience & $0.10^{*}$ & $0.03 *$ & $0.37 *$ & $0.16^{*}$ & $0.04 *$ & -0.02 & $-0.04 *$ & -0.02 & 1 & & & & & \\
\hline 10 & Number of contacts & $0.26^{*}$ & $0.24 *$ & $0.38 *$ & $0.23^{*}$ & -0.02 & $-0.06^{*}$ & $0.02 *$ & $0.05^{*}$ & $0.19 *$ & 1 & & & & \\
\hline 11 & Venture size & $-0.24 *$ & $-0.08 *$ & $0.40 *$ & $0.07 *$ & $-0.03 *$ & 0.01 & -0.01 & 0.01 & $0.12 *$ & $0.10 *$ & 1 & & & \\
\hline 12 & Sector & -0.01 & -0.002 & -0.01 & $0.04 *$ & 0.003 & $0.06^{*}$ & -0.001 & -0.01 & -0.001 & -0.02 & -0.01 & 1 & & \\
\hline 13 & GDP growth & 0.01 & $-0.15^{*}$ & $-0.09^{*}$ & -0.01 & -0.01 & $0.03 *$ & $-0.06 *$ & $-0.03 *$ & $-0.04 *$ & -0.01 & $0.04 *$ & 0.01 & 1 & \\
\hline 14 & Industry share ( $\%$ of GDP) & $-0.14 *$ & $-0.18 *$ & -0.01 & $-0.04 *$ & -0.01 & -0.002 & 0.02 & -0.02 & $-0.04 *$ & $-0.06^{*}$ & $-0.04 *$ & -0.0004 & $-0.05^{*}$ & 1 \\
\hline 15 & Host country & $-0.05 *$ & 0.02 & -0.003 & $-0.09 *$ & -0.01 & 0.02 & 0.01 & $-0.03 *$ & $-0.03 *$ & -0.01 & 0.02 & 0.01 & $-0.07 *$ & $0.10^{*}$ \\
\hline
\end{tabular}

(No. of observations $=7,857$ )

* Correlation coefficients significant at the $5 \%$ level or lower 
Table 3b. Correlations of Variables (Foreign Entrepreneur Sample)

\begin{tabular}{|c|c|c|c|c|c|c|c|c|c|c|c|c|c|c|c|}
\hline & & 1 & 2 & 3 & 4 & 5 & 6 & 7 & 8 & 9 & 10 & 11 & 12 & 13 & 3 \\
\hline 1 & Corruption willingness & 1 & & & & & & & & & & & & & \\
\hline 2 & Oil price shock & $0.49 *$ & 1 & & & & & & & & & & & & \\
\hline 3 & CPI difference & $-0.29 *$ & 0.01 & 1 & & & & & & & & & & & \\
\hline 4 & Gender & $0.15^{*}$ & -0.01 & $-0.25^{*}$ & 1 & & & & & & & & & & \\
\hline 5 & Age group (28-37) & $0.08^{*}$ & $0.10^{*}$ & $-0.16^{*}$ & $0.12 *$ & 1 & & & & & & & & & \\
\hline 6 & Age group (38-47) & $-0.13^{*}$ & $-0.04 *$ & $0.16^{*}$ & $-0.07 *$ & $-0.33^{*}$ & 1 & & & & & & & & \\
\hline 7 & Age group (48-57) & $-0.10 *$ & 0.03 & $0.23 *$ & $-0.12 *$ & $-0.30^{*}$ & $-0.22 *$ & 1 & & & & & & & \\
\hline 9 & Prior entrepreneurial experience & $0.22 *$ & -0.01 & $-0.47 *$ & $0.20 *$ & $0.17 *$ & $-0.05^{*}$ & $-0.13 *$ & $-0.08 *$ & 1 & & & & & \\
\hline 10 & Number of contacts & $0.29 *$ & $0.40^{*}$ & $-0.07 *$ & 0.02 & $0.07 *$ & $-0.05^{*}$ & $-0.04 *$ & $0.03 *$ & $0.08 *$ & 1 & & & & \\
\hline 11 & Venture size & $-0.40 *$ & $-0.36^{*}$ & $0.04 *$ & $-0.04 *$ & -0.01 & $0.04 *$ & $-0.03 *$ & $-0.03 *$ & $-0.03 *$ & $-0.16^{*}$ & 1 & & & \\
\hline 12 & Sector & -0.02 & 0.002 & $0.05 *$ & 0.01 & -0.02 & $0.11 *$ & 0.01 & -0.003 & -0.01 & -0.03 & 0.004 & 1 & & \\
\hline 13 & GDP growth & $-0.04 *$ & $-0.12 *$ & $0.13 *$ & 0.03 & 0.02 & -0.03 & $-0.09 *$ & $-0.04 *$ & -0.001 & $0.03 *$ & 0.02 & 0.01 & 1 & 1 \\
\hline 14 & Industry share ( $\%$ of GDP) & $-0.28 *$ & $-0.18 *$ & $0.11 *$ & $-0.06^{*}$ & -0.02 & 0.03 & 0.03 & -0.01 & $-0.06^{*}$ & $-0.10^{*}$ & $0.07 *$ & 0.02 & -0.02 & \\
\hline 15 & Host country & $-0.09 *$ & 0.02 & $-0.06 *$ & $-0.06^{*}$ & -0.01 & $-0.04 *$ & -0.01 & $-0.04 *$ & $-0.11 *$ & -0.01 & 0.002 & $0.04 *$ & $-0.08^{*}$ & 0.09 \\
\hline
\end{tabular}

Table 4. T-tests for the Equality of Means of the Variables in the Drop-out and Survived Samples

\begin{tabular}{lccc}
\hline & The sample of drop-out & The sample of survived & t-test \\
\hline No. of individuals & 366 & 1229 & $-3.89^{* * *}$ \\
Corruption Willingness & -0.096 & 0.042 & $-3.64^{* * *}$ \\
Foreign & $44.2 \%$ & $50.9 \%$ & $-2.7^{* * *}$ \\
Venture size & 5.58 & 5.85 & $-5.99^{* *}$ \\
Prior venturing experience & 2.04 & 2.41 & 4.89 \\
No. of contacts & 8.06 & 9.08 & 1.66 \\
Gender & 0.77 & 0.74 & $-3.79 * * *$ \\
Age of entrepreneur & 34.83 & 36.29 & $1.96^{*}$ \\
Sectors & 4 & 3.87 &
\end{tabular}


Table 5. The Selection Model: Probit Analysis of Survival

\begin{tabular}{lc}
\hline & Model 1 \\
& Survival $(0 / 1)$ \\
\hline Corruption willingness & 0.011 \\
Log sales & $(0.026)$ \\
& $0.317^{* * *}$ \\
Gender & $(0.028)$ \\
& $-0.206^{* * *}$ \\
Foreign & $(0.052)$ \\
& $0.114^{*}$ \\
Age of entrepreneur & $(0.052)$ \\
& $0.007 * * *$ \\
Prior entrepreneurial experience & $(0.002)$ \\
Number of contacts & $0.044^{* * *}$ \\
Venture size & $(0.013)$ \\
& -0.005 \\
Constant & $(0.004)$ \\
Observations & $0.024 * *$ \\
\hline
\end{tabular}

Standard errors in parentheses $* * * \mathrm{p}<0.001, * * \mathrm{p}<0.01, * \mathrm{p}<0.05$

Table 6. T-tests for the Equality of Means of the Variables in the two Matched Sample after Propensity Score Matching Analysis

\begin{tabular}{lccccc}
\hline Variable & Foreign Entrepreneurs & Local Entrepreneurs & \%bias & $\mathrm{t}$ & $\mathrm{p}>\mathrm{t}$ \\
\hline No. of individuals & 529 & 426 & & & \\
Gender & 0.78 & 0.77 & 1.1 & 0.26 & 0.80 \\
Age & 37.02 & 37.84 & -8 & -1.76 & 0.08 \\
Prior venturing experience & 2.42 & 2.46 & -2.4 & -0.54 & 0.59 \\
No. of contacts & 9.46 & 9.35 & 2 & 0.47 & 0.64 \\
Venture size & 6.35 & 6.36 & -0.4 & -0.08 & 0.94 \\
Sector_Consulting & 0.09 & 0.10 & -2.4 & -0.58 & 0.56 \\
Sector_General Trade & 0.11 & 0.11 & -0.6 & -0.13 & 0.89 \\
Sector_IT & 0.15 & 0.16 & -1.8 & -0.41 & 0.68 \\
Sector_Import/Export & 0.20 & 0.19 & 2.9 & 0.69 & 0.49 \\
Sector_Real Estate & 0.23 & 0.22 & 3.5 & 0.81 & 0.42 \\
Sector_Tourism & 0.03 & 0.03 & 5.8 & 1.25 & 0.21 \\
\hline
\end{tabular}

Standard errors in parentheses $* * * \mathrm{p}<0.001,{ }^{* *} \mathrm{p}<0.01,{ }^{*} \mathrm{p}<0.05$ 
Table 7. Difference in Difference Analysis of Corruption Willingness with Matched Foreign and Local Entrepreneurs (H1)

\begin{tabular}{|c|c|c|}
\hline & Model 1 & Model 2 \\
\hline Oil price shock & $\begin{array}{c}0.021 \\
(0.049)\end{array}$ & $\begin{array}{l}-0.061 \\
(0.045)\end{array}$ \\
\hline Foreign & $\begin{array}{c}-0.882^{* * *} \\
(0.052)\end{array}$ & $\begin{array}{c}-0.732 * * * \\
(0.049)\end{array}$ \\
\hline Diff-in-Diff & $\begin{array}{c}1.005^{* * *} \\
(0.077)\end{array}$ & $\begin{array}{c}0.659 * * * \\
(0.073)\end{array}$ \\
\hline Gender & & $\begin{array}{c}0.711 * * * \\
(0.040)\end{array}$ \\
\hline Age group (28-37) & & $\begin{array}{c}-0.241^{* * *} \\
(0.043)\end{array}$ \\
\hline Age group (38-47) & & $\begin{array}{c}-0.292^{* * *} \\
(0.046)\end{array}$ \\
\hline Age group (48-57) & & $\begin{array}{c}-0.162 * * \\
(0.050)\end{array}$ \\
\hline Age group (58-67) & & $\begin{array}{l}-0.194^{*} \\
(0.082)\end{array}$ \\
\hline Prior entrepreneurial experience & & $\begin{array}{l}0.031^{* *} \\
(0.011)\end{array}$ \\
\hline Number of contacts & & $\begin{array}{c}0.020^{* * *} \\
(0.003)\end{array}$ \\
\hline Venture size & & $\begin{array}{c}-0.048^{* * *} \\
(0.006)\end{array}$ \\
\hline Sector_Consulting & & $\begin{array}{l}-0.080 \\
(0.061)\end{array}$ \\
\hline Sector_General Trade & & $\begin{array}{l}-0.099 \\
(0.059)\end{array}$ \\
\hline Sector_IT & & $\begin{array}{l}-0.022 \\
(0.053)\end{array}$ \\
\hline Sector_Import/Export & & $\begin{array}{l}-0.093 \\
(0.050)\end{array}$ \\
\hline Sector_Real Estate & & $\begin{array}{l}-0.096^{*} \\
(0.048)\end{array}$ \\
\hline Sector_Tourism & & $\begin{array}{c}-0.275^{* *} \\
(0.096)\end{array}$ \\
\hline GDP growth & & $\begin{array}{c}0.000 \\
(0.010)\end{array}$ \\
\hline Industry share ( $\%$ of GDP) & & $\begin{array}{c}-0.093 * * * \\
(0.017)\end{array}$ \\
\hline Host country dummies & & Yes \\
\hline IMR & $\begin{array}{c}0.434 \\
(0.257)\end{array}$ & $\begin{array}{c}2.067 * * * \\
(0.283)\end{array}$ \\
\hline Constant & $\begin{array}{c}0.359^{* * *} \\
(0.064)\end{array}$ & $\begin{array}{c}0.574 * * * \\
(0.130)\end{array}$ \\
\hline Observations & 2,206 & 2,206 \\
\hline R-squared & 0.222 & 0.407 \\
\hline
\end{tabular}


Table 8. Panel Regression of Corruption Willingness (Robustness Test of H1)

\begin{tabular}{|c|c|c|c|}
\hline & Model 1 & Model 2 & Model 3 \\
\hline Oil price shock & & $\begin{array}{c}0.066 * * * \\
(0.019)\end{array}$ & $\begin{array}{c}-0.182 * * * \\
(0.021)\end{array}$ \\
\hline Foreign & & $\begin{array}{c}-0.324 * * * \\
(0.030)\end{array}$ & $\begin{array}{c}-0.669 * * * \\
(0.033)\end{array}$ \\
\hline Oil price shock X Foreign & & & $\begin{array}{c}0.701 * * * \\
(0.030)\end{array}$ \\
\hline Gender & $\begin{array}{c}0.846^{* * *} \\
(0.031)\end{array}$ & $\begin{array}{c}0.908 * * * \\
(0.030)\end{array}$ & $\begin{array}{c}0.883 * * * \\
(0.031)\end{array}$ \\
\hline Age group (28-37) & $\begin{array}{c}-0.206 * * * \\
(0.026)\end{array}$ & $\begin{array}{c}-0.240 * * * \\
(0.026)\end{array}$ & $\begin{array}{c}-0.230 * * * \\
(0.025)\end{array}$ \\
\hline Age group (38-47) & $\begin{array}{c}-0.352 * * * \\
(0.033)\end{array}$ & $\begin{array}{c}-0.382 * * * \\
(0.032)\end{array}$ & $\begin{array}{c}-0.331 * * * \\
(0.032)\end{array}$ \\
\hline Age group (48-57) & $\begin{array}{c}-0.183 * * * \\
(0.038)\end{array}$ & $\begin{array}{c}-0.195^{* * *} \\
(0.037)\end{array}$ & $\begin{array}{c}-0.139 * * * \\
(0.036)\end{array}$ \\
\hline Age group (58-67) & $\begin{array}{l}-0.130 * \\
(0.065)\end{array}$ & $\begin{array}{c}-0.168 * * \\
(0.064)\end{array}$ & $\begin{array}{c}-0.118+ \\
(0.063)\end{array}$ \\
\hline Prior entrepreneurial experience & $\begin{array}{c}-0.022 * * \\
(0.008)\end{array}$ & $\begin{array}{c}0.010 \\
(0.009)\end{array}$ & $\begin{array}{c}0.031 * * * \\
(0.009)\end{array}$ \\
\hline Number of contacts & $\begin{array}{c}0.010 * * * \\
(0.002)\end{array}$ & $\begin{array}{c}0.012 * * * \\
(0.002)\end{array}$ & $\begin{array}{c}0.005 * * * \\
(0.001)\end{array}$ \\
\hline Venture size & $\begin{array}{c}-0.100^{* * *} \\
(0.003)\end{array}$ & $\begin{array}{c}-0.091 * * * \\
(0.003)\end{array}$ & $\begin{array}{c}-0.066^{* * *} * \\
(0.003)\end{array}$ \\
\hline Sector_Consulting & $\begin{array}{c}-0.056 \\
(0.052)\end{array}$ & $\begin{array}{l}-0.045 \\
(0.050)\end{array}$ & $\begin{array}{l}-0.049 \\
(0.050)\end{array}$ \\
\hline Sector_General Trade & $\begin{array}{c}-0.095+ \\
(0.050)\end{array}$ & $\begin{array}{l}-0.098 * \\
(0.048)\end{array}$ & $\begin{array}{l}-0.103 * \\
(0.048)\end{array}$ \\
\hline Sector_IT & $\begin{array}{l}-0.035 \\
(0.047)\end{array}$ & $\begin{array}{c}-0.032 \\
(0.044)\end{array}$ & $\begin{array}{l}-0.036 \\
(0.045)\end{array}$ \\
\hline Sector_Import/Export & $\begin{array}{c}-0.053 \\
(0.043)\end{array}$ & $\begin{array}{l}-0.065 \\
(0.041)\end{array}$ & $\begin{array}{l}-0.071+ \\
(0.041)\end{array}$ \\
\hline Sector_Real Estate & $\begin{array}{l}-0.009 \\
(0.042)\end{array}$ & $\begin{array}{l}-0.011 \\
(0.040)\end{array}$ & $\begin{array}{l}-0.017 \\
(0.040)\end{array}$ \\
\hline Sector_Tourism & $\begin{array}{c}-0.094 \\
(0.089)\end{array}$ & $\begin{array}{l}-0.093 \\
(0.085)\end{array}$ & $\begin{array}{l}-0.103 \\
(0.085)\end{array}$ \\
\hline GDP growth & $\begin{array}{l}0.010 * \\
(0.004)\end{array}$ & $\begin{array}{c}0.012 * * \\
(0.004)\end{array}$ & $\begin{array}{c}0.006 \\
(0.004)\end{array}$ \\
\hline Industry share ( $\%$ of GDP) & $\begin{array}{c}-0.090^{* * *} \\
(0.008)\end{array}$ & $\begin{array}{c}-0.084 * * * \\
(0.008)\end{array}$ & $\begin{array}{c}-0.085 * * * \\
(0.008)\end{array}$ \\
\hline Host country dummies & Yes & Yes & Yes \\
\hline IMR & $\begin{array}{c}3.326^{* * *} \\
(0.104)\end{array}$ & $\begin{array}{c}3.123 * * * \\
(0.123)\end{array}$ & $\begin{array}{c}2.237 * * * \\
(0.124)\end{array}$ \\
\hline Constant & $\begin{array}{c}0.949 * * * \\
(0.073)\end{array}$ & $\begin{array}{c}0.836 * * * \\
(0.075)\end{array}$ & $\begin{array}{c}0.649 * * * \\
(0.075)\end{array}$ \\
\hline Observations & 7,857 & 7,857 & 7,857 \\
\hline Number of entrepreneurs & 1,595 & 1,595 & 1,595 \\
\hline
\end{tabular}

Standard errors in parentheses

$* * * \mathrm{p}<0.001, * * \mathrm{p}<0.01, * \mathrm{p}<0.05$ 
Table 9. Moderating Effects of CPI Difference on Corruption Willingness (H2)

\begin{tabular}{|c|c|c|c|}
\hline & Model 1 & Model 2 & Model 3 \\
\hline Oil price shock & & $\begin{array}{c}0.443 * * * \\
(0.032)\end{array}$ & $\begin{array}{c}0.049 \\
(0.041)\end{array}$ \\
\hline CPI difference & & $\begin{array}{c}-0.436 * * * \\
(0.033)\end{array}$ & $\begin{array}{c}-0.881 * * * \\
(0.044)\end{array}$ \\
\hline Oil price shock X CPI difference & & & $\begin{array}{c}0.772 * * * \\
(0.051)\end{array}$ \\
\hline Gender & $\begin{array}{c}0.353^{* * *} \\
(0.037)\end{array}$ & $\begin{array}{c}0.207^{* * *} \\
(0.035)\end{array}$ & $\begin{array}{c}0.162^{* * *} \\
(0.035)\end{array}$ \\
\hline Age group (28-37) & $\begin{array}{c}-0.228^{* * *} \\
(0.031)\end{array}$ & $\begin{array}{c}-0.221 * * * \\
(0.029)\end{array}$ & $\begin{array}{c}-0.185^{* * *} \\
(0.029)\end{array}$ \\
\hline Age group (38-47) & $\begin{array}{c}-0.401 * * * \\
(0.036)\end{array}$ & $\begin{array}{c}-0.292 * * * \\
(0.034)\end{array}$ & $\begin{array}{c}-0.249 * * * \\
(0.034)\end{array}$ \\
\hline Age group (48-57) & $\begin{array}{c}-0.454^{* * * *} \\
(0.038)\end{array}$ & $\begin{array}{c}-0.286^{* * *} \\
(0.038)\end{array}$ & $\begin{array}{c}-0.235^{* * *} \\
(0.038)\end{array}$ \\
\hline Age group (58-67) & $\begin{array}{c}-0.423 * * * \\
(0.074)\end{array}$ & $\begin{array}{c}-0.250^{* * *} \\
(0.071)\end{array}$ & $\begin{array}{c}-0.239 * * * \\
(0.070)\end{array}$ \\
\hline Prior entrepreneurial experience & $\begin{array}{l}0.016^{*} \\
(0.008)\end{array}$ & $\begin{array}{l}-0.004 \\
(0.008)\end{array}$ & $\begin{array}{c}0.008 \\
(0.008)\end{array}$ \\
\hline Number of contacts & $\begin{array}{l}0.004+ \\
(0.002)\end{array}$ & $\begin{array}{c}0.000 \\
(0.002)\end{array}$ & $\begin{array}{l}-0.003+ \\
(0.002)\end{array}$ \\
\hline Venture size & $\begin{array}{c}-0.119^{* * *} \\
(0.004)\end{array}$ & $\begin{array}{c}-0.094 * * * \\
(0.004)\end{array}$ & $\begin{array}{c}-0.088^{* * *} \\
(0.004)\end{array}$ \\
\hline Sector_Consulting & $\begin{array}{l}-0.027 \\
(0.047)\end{array}$ & $\begin{array}{l}-0.037 \\
(0.043)\end{array}$ & $\begin{array}{l}-0.038 \\
(0.043)\end{array}$ \\
\hline Sector_General Trade & $\begin{array}{l}-0.002 \\
(0.044)\end{array}$ & $\begin{array}{c}0.022 \\
(0.041)\end{array}$ & $\begin{array}{c}0.019 \\
(0.041)\end{array}$ \\
\hline Sector_IT & $\begin{array}{l}-0.004 \\
(0.042)\end{array}$ & $\begin{array}{l}-0.021 \\
(0.039)\end{array}$ & $\begin{array}{l}-0.022 \\
(0.039)\end{array}$ \\
\hline Sector_Import/Export & $\begin{array}{c}0.012 \\
(0.039)\end{array}$ & $\begin{array}{c}0.025 \\
(0.036)\end{array}$ & $\begin{array}{c}0.026 \\
(0.036)\end{array}$ \\
\hline Sector_Real Estate & $\begin{array}{l}-0.016 \\
(0.038)\end{array}$ & $\begin{array}{c}-0.001 \\
(0.035)\end{array}$ & $\begin{array}{l}-0.001 \\
(0.035)\end{array}$ \\
\hline Sector_Tourism & $\begin{array}{c}0.006 \\
(0.084)\end{array}$ & $\begin{array}{l}-0.020 \\
(0.078)\end{array}$ & $\begin{array}{l}-0.022 \\
(0.078)\end{array}$ \\
\hline GDP growth & $\begin{array}{l}-0.014^{*} \\
(0.007)\end{array}$ & $\begin{array}{l}-0.008 \\
(0.007)\end{array}$ & $\begin{array}{l}-0.012+ \\
(0.006)\end{array}$ \\
\hline Industry share ( $\%$ of GDP) & $\begin{array}{c}-0.174 * * * \\
(0.012)\end{array}$ & $\begin{array}{c}-0.140^{* * *} \\
(0.012)\end{array}$ & $\begin{array}{c}-0.124 * * * \\
(0.012)\end{array}$ \\
\hline Host country dummies & Yes & Yes & Yes \\
\hline IMR & $\begin{array}{c}4.002 * * * \\
(0.141)\end{array}$ & $\begin{array}{c}2.512 * * * \\
(0.167)\end{array}$ & $\begin{array}{c}1.590 * * * \\
(0.173)\end{array}$ \\
\hline Constant & $\begin{array}{c}1.749 * * * \\
(0.086)\end{array}$ & $\begin{array}{c}1.456^{* * *} \\
(0.095)\end{array}$ & $\begin{array}{c}1.459^{* * * *} \\
(0.093)\end{array}$ \\
\hline Observations & 3,948 & 3,948 & 3,948 \\
\hline R-squared & 0.519 & 0.519 & 0.519 \\
\hline Number of entrepreneurs & 777 & 777 & 777 \\
\hline Chi2 & 4204 & 4204 & 4204 \\
\hline
\end{tabular}

Standard errors in parentheses

$* * * \mathrm{p}<0.001,{ }^{* *} \mathrm{p}<0.01,{ }^{*} \mathrm{p}<0.05,+\mathrm{p}<0.1$ 